\title{
RETURNS TO HUMAN CAPITAL UNDER THE COMMUNIST WAGE GRID AND DURING THE TRANSITION TO A MARKET ECONOMY
}

\author{
Daniel Münich, Jan Svejnar, and Katherine Terrell*
}

\begin{abstract}
We estimate returns to human capital during communism and the transition using data on 2,284 men in the Czech Republic. We show: (a) extremely low and constant rates of return to education under the communist wage grid and dramatic increases in transition, which do not differ by firm ownership, (b) radical changes in returns to several fields of study and "sheepskin effects" in both regimes, (c) identical wageexperience profile in both regimes, (d) similar 1996 returns to human capital obtained in communism and in transition, and (e) changes in the interindustry wage structure. A decomposition of the variance of wages finds individuals' unobservable effects from communism to persist into transition, but most of the variance is due to unobservable effects introduced in the transition.
\end{abstract}

\section{Introduction}

$\mathrm{D}$ uring a significant part of the twentieth century, over one-third of the world's population lived under the communist system. A large proportion of those who were in the labor force had their wages set according to a centrally determined wage grid. Although the effects of the grid per se have never been formally analyzed, there has been some evidence that the earnings structures in centrally planned economies were greatly compressed and that there was decompression during the transition to a market system. In this paper we use new microdata to (a) analyze returns to human capital under the communist wage grid and (b) examine how wages and returns to human capital changed in the emerging market economy as the grid was supplanted by free wage setting in the sector composed of newly created private (de novo) firms and a modified wage grid in the public sector and many privatized firms.

In analyzing the shift from the Communist wage grid, we have selected the Czech Republic because it is an excellent prototype of a sudden change of regimes among the leading transition economies. In the other transition countries, such as Poland and Hungary, central planners started losing control well before the 1989 revolutions, and their adherence to the wage grid diminished as bargaining between firms and planners gained in importance (see, e.g., Rutkowski, 1994). In the Czech Republic, the system remained intact until the very end of the communist regime, and evidence from large firm-level data sets indicates that there was no significant rent sharing by workers (Basu, Estrin, \& Svejnar, 1999). Moreover, whereas the Polish and Hungarian economies had significant private sectors already before the transition, the Czech economy was almost $100 \%$ stateowned until 1990, and then it underwent one of the most

Received for publication February 14, 2002. Revision accepted for publication May 25, 2004

* CERGE-EI (Prague); Ross School of Business and Department of Economics, University of Michigan; Ross School of Business and Ford School of Public Policy, University of Michigan, respectively.

In preparing the paper, the authors were in part supported by grants from the National Science Foundation (grant no. SBR-951-2001), PHARE (grant no. CZ 9406 01-01-03), the National Council for East European and rapid and extensive privatizations in the former Soviet bloc. ${ }^{1}$

The human capital studies carried out on the transition economies to date have examined returns in a crosssectional setting, using one set of individuals at an early point in time during transition and in some cases also another set of individuals (sometimes from a different survey design) at a point in time during communism. ${ }^{2} \mathrm{We}$ complement these studies in several ways:

(a) We estimate the determinants of wages and returns to human capital using data on the same individuals during a large part of the communist period and the first 6 years of transition.

(b) We make use of the panel data to develop and assess if some individuals had high or low wage premia related to unobservable characteristics and whether these premia carried over into the transition period. In particular, we develop and apply a method decomposing the variance of worker-specific wages into components due to observable determinants and unobservable determinants in the old versus the new regime.

(c) We use actual years of schooling as a measure of education, rather than imputed years based on the highest degree obtained. We use the information on actual years of education and highest level attained for each individual to test for the bias created by using imputed measures of schooling and to measure sheepskin effects (jumps in wages when degrees are received, controlling for years of education).

(d) We test directly whether education and experience gained in the communist and in the postcommunist periods generate the same rate of return during the postcommunist period.

(e) We examine the effect of firm ownership on returns to human capital during the transition. Privatization and the creation of new firms are key aspects of the

Eurasian Studies (contract no. 812-32), and the World Bank. The authors would like to thank two anonymous referees, Orley Ashenfelter, Jan Kmenta, George Johnson, Stepan Jurajda, Jiri Vecernik, and Jonathan Wadsworth, as well as the participants in the CERGE-EI Applied Microeconomics Seminar (October 1998), the Comparative Economic Development Seminar at the University of Michigan (November 1998), the North American Meetings of the Econometric Society (January 1999), the conference on "Labour Market Adjustments and Restructuring in Transition Economies," Romania (April 1999), and the 1999 CEPR-IZA Summer Symposium on Labour Economics, for valuable comments.

${ }^{1}$ See, for example, Dyba and Svejnar (1995).

${ }^{2}$ See, for example Bird, Schwartze, and Wagner (1994), Chase (1998), Flanagan (1996, 1998), Jones and Ilayperuma (1994), Krueger and Pischke (1995), Nesterova and Sabirianova (1999), Orazem and Vodopivec (1997), and Rutkowski (1996). 
transition process, and understanding their impact on the wage structure is of great importance.

(f) We estimate changes in the structure of wages by industry and field of study (given attained education) to assess the impact of changes in the structure of the economy on wages.

(g) Finally, existing studies by Krueger and Pischke (1995), Chase (1998), and Flanagan (1998) provide somewhat contradictory estimates of the returns to education and experience during the communist and postcommunist regimes in a similar context. We provide additional evidence and ideas about how one might reconcile the differences in the various findings. ${ }^{3}$

In order to carry out our analysis, we collected data on the work histories of 2,284 men from a stratified random sample of households in the Czech Republic. Most of the men worked under communism, all worked during at least part of the 1990-1996 transition period, and many worked in December 1996, the date of our survey. Using these data, we analyze the evolution of the returns to education and experience in various parts of the 1948-1989 communist era and during the 1991-1996 period of transition from plan to market. To our knowledge, no other data set provides information on individuals for such long periods of communism and transition. ${ }^{4}$

We demonstrate that the communist system used the wage grid to set and maintain an extremely low rate of return to education. We also show that the transition resulted in a major increase in the rates of return to education, which reached west European levels by 1996. Unlike Flanagan (1998), we find this increase in all ownership categories of firms. ${ }^{5}$ Hence, as the economy opened to world competition, returns to education in the public sector [state-owned enterprises (SOEs) and public administration] and privatized SOEs did not deviate significantly from the market-driven, de novo firms. The data suggest that at the start of the transition de novo firms were the market leaders in setting wages, but that state and privatized firms adjusted their wage grids and almost caught up with wages in the de novo firms by 1996.

We run regressions with different specifications of the education variable, using highest level (degree) attained versus years of education, testing for sheepskin effects, and estimating returns to fields of study. We find that those who have obtained (vocational) high school and university de-

\footnotetext{
${ }^{3}$ Krueger and Pischke (1995) deal with East Germany, and Chase (1998) and Flanagan (1998) with the Czech Republic. Unlike Hungary and Poland, East Germany and the Czech Republic both adhered to the wage grid until the very end of the communist regime.

${ }^{4}$ The corresponding study of women is in Münich, Svejnar, and Terrell (2005). A potential weakness of the retrospective data set is recall error, as individuals may not accurately remember their past wages. As we discuss below, we check the magnitude and minimize the effect of this error

${ }^{5}$ Chase (1998) is not able to make this comparison, for he does not have data on firm ownership.
}

grees experienced more rapid rates of increase in their returns than those with basic education (junior high school or apprentices). The sheepskin effect is prevalent and is especially detectable in transition and for higher levels of education in both regimes. Certain fields of study have experienced tremendous increases in their returns (e.g., law), while others have not gained in the new market economy (e.g., health and education). We also show that the earlier studies may overestimate the rate of return to education by using years of education imputed from the highest degree obtained rather than actual years of schooling as an explanatory variable.

Our estimates of the effects of experience on earnings indicate that men's wage-experience profile was concave in both regimes and that on average it did not change from the communist to the transition period. This finding differs from Chase (1998), Flanagan (1998), and to a lesser extent Krueger and Pischke (1995), who find wage-experience profiles becoming flatter during the new regime. When we estimate these profiles for workers in firms with different ownership types during the transition, we find that the de novo firms display a steeper and more concave profile than SOEs and public administration, hence paying a higher return to recent entrants' short experience than SOEs and public administration. We also find that private firms tend to pay higher wages than the SOEs and public administration, ceteris paribus.

We find that education and work experience gained during the transition do not have higher returns than education and experience gained under communism. In fact, returns on apprenticeship and vocational education are found to be lower for those who obtained this education during the transition, suggesting that the major investment in this type of education under communism was excessive. We also show that the interindustry wage structure changed substantially as the transition unfolded between 1989 and 1996. In particular, men working in mining and quarrying lost much of their former wage premium, while those in trade, transport and telecommunications, and light manufacturing gained significantly. The changes are in part attributable to the de novo firms, as they tend to pay a higher wage premium, irrespective of a worker's human capital, in trade, transport and telecommunications, and other sectors of the economy.

Finally, we develop and apply a new methodology for decomposing the variance of worker-specific wages into components due to observable and unobservable determinants in communism versus transition. We find that the variance in wages due to unobserved effects dominates the variance due to observable determinants. Moreover, while over one-half of the total variance is brought about by new unobservable characteristics introduced by the transition, there is considerable persistence of unobservable, individualspecific wage effects (e.g., skill premia) from communism into the transition. 
Table 1.-Wage Grids in the Communist and Postcommunist Periods

\begin{tabular}{|c|c|c|c|c|c|c|c|c|c|c|c|c|}
\hline \multirow{4}{*}{$\begin{array}{c}\text { Salary } \\
\text { Class }\end{array}$} & & \multicolumn{11}{|c|}{ A. 1985-1989 Wage Grid for White-Collar Workers in Czechoslovakia* } \\
\hline & & \multicolumn{11}{|c|}{ Wage } \\
\hline & & \multicolumn{5}{|c|}{ (a) All Industries except Those in (b) } & & \multicolumn{5}{|c|}{ (b) Heavy Industry and Construction } \\
\hline & & I & \multicolumn{2}{|l|}{ Ia } & $\mathrm{Ib}$ & Bonus & & II & IIa & \multicolumn{2}{|c|}{$\cdots$} & $\mathrm{Vb}$ \\
\hline 1 & & 1,000 & - & & - & 300 & & - & - & & & - \\
\hline 2 & & 1,100 & - & & - & 300 & & - & - & & & - \\
\hline 3 & & 1,200 & - & & - & 350 & & - & - & & & - \\
\hline 4 & & 1,300 & - & & - & 400 & & - & - & & & - \\
\hline 5 & & 1,450 & - & & - & 450 & & - & - & & & - \\
\hline 6 & & 1,600 & 1,750 & & - & 500 & & 1,700 & 1,850 & & & - \\
\hline 7 & & 1,750 & 1,950 & & - & 550 & & 1,850 & 2,050 & & & - \\
\hline 8 & & 1,950 & 2,150 & & 2,350 & 600 & & 2,050 & 2,250 & & & 3,100 \\
\hline 9 & & 2,150 & 2,350 & & 2,600 & 650 & & 2,250 & 2,450 & & & 3,400 \\
\hline 10 & & 2,350 & 2,600 & & 2,850 & 700 & & 2,450 & 2,700 & & & 3,750 \\
\hline : & & $\vdots$ & $\vdots$ & & $\vdots$ & : & & $\vdots$ & $\vdots$ & & & $\vdots$ \\
\hline 20 & & 6,300 & - & & - & 1,800 & & 6,500 & - & & & - \\
\hline 21 & & 7,100 & - & & - & 1,900 & & 7,200 & - & & & - \\
\hline \multicolumn{13}{|c|}{ B. 1998 Wage Grid for the Public Sector in the Czech Republic* } \\
\hline \multirow{2}{*}{$\begin{array}{l}\text { Salary } \\
\text { Class }\end{array}$} & \multicolumn{12}{|c|}{ Wage by years of experience } \\
\hline & $<1$ & $1-2$ & $3-4$ & $5-6$ & $7-9$ & $10-12$ & $13-15$ & $16-19$ & $20-23$ & $24-27$ & $28-32$ & $>32$ \\
\hline 1 & 3,250 & 3,390 & 3,550 & 3,700 & 3,850 & 4,000 & 4,170 & 4,330 & 4,490 & 4,660 & 4,820 & 4,980 \\
\hline 2 & 3,560 & 3,720 & 3,880 & 4,050 & 4,210 & 4,380 & 4,540 & 4,720 & 4,900 & 5,080 & 5,250 & 5,430 \\
\hline$\vdots$ & $\vdots$ & $\vdots$ & $\vdots$ & $\vdots$ & $\vdots$ & $:$ & $\vdots$ & : & : & $\vdots$ & : & : \\
\hline 11 & 8,800 & 9,250 & 9,710 & 10,170 & 10,620 & 11,080 & 11,540 & 11,980 & 12,440 & 12,910 & 13,370 & 13,840 \\
\hline 12 & 10,000 & 10,520 & 11,030 & 11,560 & 12,070 & 12,590 & 13,120 & 13,640 & 14,170 & 14,710 & 15,230 & 15,760 \\
\hline
\end{tabular}

See text for description.
Sources: Ministry of Labor and Social Affairs $(1985,1986,1998)$.

The paper is organized as follows: In section II we provide a brief institutional background; in section III we describe our data and methodology. Section IV contains our empirical findings on returns to education under the communist grid and during the transition, and in section $\mathrm{V}$ we present the corresponding returns to experience. In section VI we analyze the returns in transition to human capital obtained under communism. The shift in interindustry wage differentials from the communist to the transition period is analyzed in section VII. In section VIII we present and apply a new method for decomposing the variance of worker-specific wages. We conclude the paper in section IX.

\section{The Wage Grids}

As in other centrally planned economies, after the 1948 communist takeover of Czechoslovakia, the government introduced a wage grid in an attempt to leave little discretion for managers or unions to set wages at the enterprise level. However, some discretion remained, as managers could award "personal evaluation bonuses" that varied across workers with the same observable characteristics and could represent as much as $30 \%$ of the base wage. While in principle the trade unions and government jointly determined the grid and the level of wages within the grid, in practice the union and government officials by and large implemented the communist party policies as set out in the central plan. ${ }^{6}$

In panel A of Table 1 we present the 1985 wage grid that was used for white collar workers in the last 5 years of communism. ${ }^{7}$ The columns represent wage levels by industry. Most workers were placed in wage tariff (class) categories I-Ib, but workers in heavy and construction industries were placed in wage tariff categories II-Vb. Within each wage tariff category, workers were placed in salary classes 1-21 on the basis of their education, experience, and occupation and the number of employees that they supervised. The grid was accompanied by a detailed handbook that permits one to determine the relationship between education or experience and wages.

The system underlying the grid evolved over time. For example, the earlier grids were sector-specific (e.g., the

\footnotetext{
${ }^{6}$ See, e.g., Windmuller (1970), Svejnar (1974a,b), Adam (1984), and Flanagan (1998). In addition to personal evaluation bonuses, the managers could influence total compensation and hence compete for workers by offering various social benefits, such as subsidized housing. However, they could not change the centrally set wage rates.

7 We could not obtain a detailed grid for blue collar workers for the mid to late $1980 \mathrm{~s}$, but we believe that the experience profile was similar to that for white collar employees. As we show in table 9 below, the interpolated wage-experience grid estimates for blue collar workers in 1982 and white collar workers in 1985 are quite similar. The grids that we present in figure 1 for 1954, 1979, and 1998 cover both blue and white collar workers.
} 

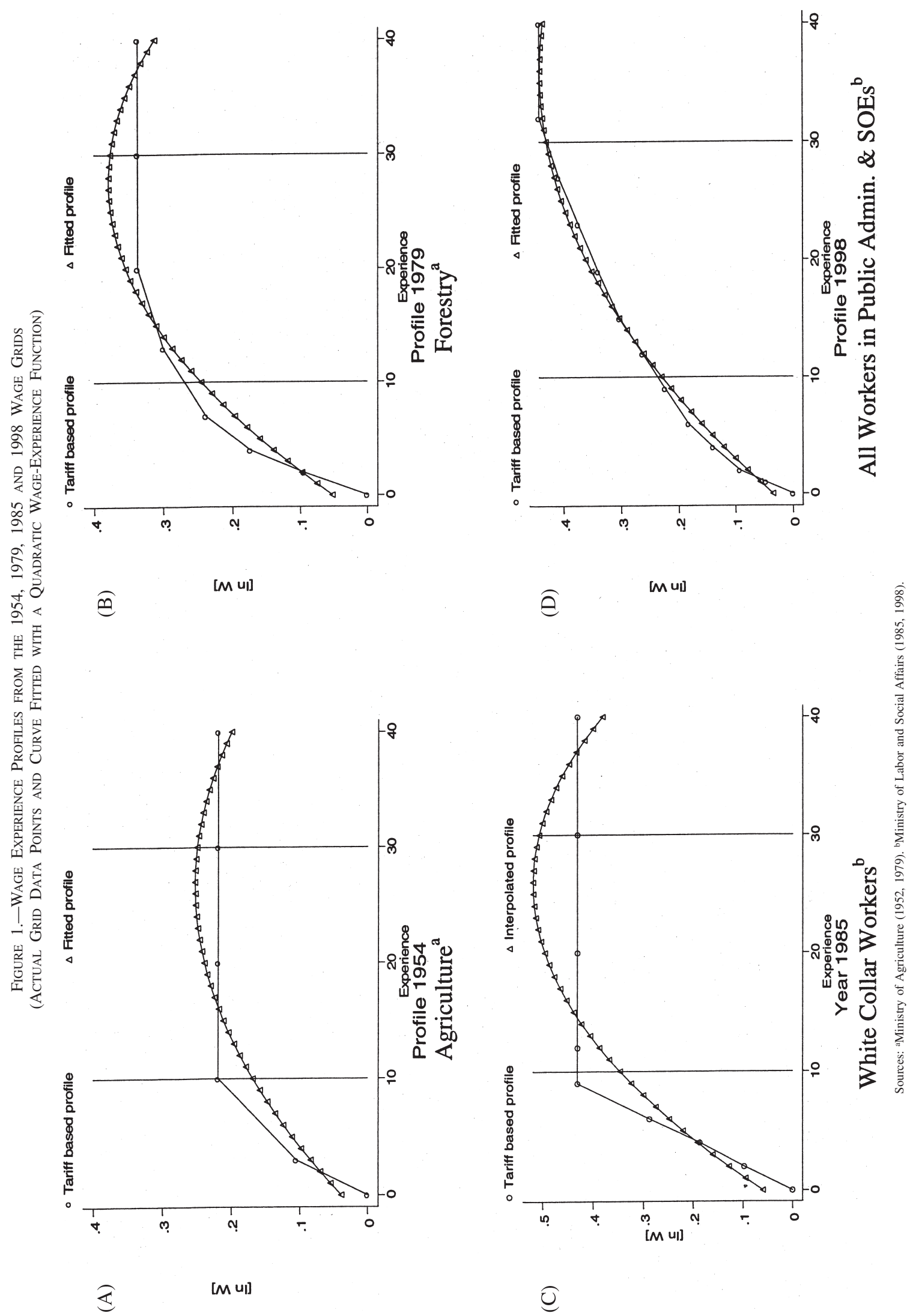
1954 grid for agriculture and 1979 grid for forestry that we depict in figure 1); the later ones were economy-wide. ${ }^{8}$ As is evident from the 1985 grid in table 1, planners favored workers in heavy industries and construction over those in other sectors. ${ }^{9}$ Adjustments were also made for the number of hours worked per week, and, as mentioned earlier, managers could at their discretion award workers significant bonuses.

The wage dispersion across the various categories in the grid was modest, given that unskilled workers were the pillar of the regime and the communist ideology dictated that wage differentials between the skilled and unskilled be kept small. ${ }^{10}$ Correspondingly, during the communist period wages were compressed and the income distribution in Czechoslovakia and the other central and east European (CEE) countries was one of the most egalitarian in the world (see, e.g., Atkinson and Micklewright, 1992).

Since the collapse of communism at the end of 1989, market forces have increasingly determined wages and employment in the de novo firms. The public sector and most privatized SOEs, however, used modified wage grids throughout the 1990s. ${ }^{11}$ In panel B of table 1 we present the wage grid used in the public sector in 1998. In comparison with its communist predecessor, this grid was substantially simplified by eliminating the industry dimension and creating 12 experience-related categories (columns), together with 12 salary classes (rows) based primarily on education. Information on the grids used by the private sector during the 1990s suggests that these grids and the accompanying rules were similar to those in the public sector, but that wage adjustments related to experience flattened out earlier than

\footnotetext{
${ }^{8}$ See Ministry of Agriculture (1952) and Ministry of Labor and Social Affairs $(1985,1986)$.

${ }^{9}$ For many years, planners favored "productive" sectors (industry, construction, and agriculture) over the "unproductive" sectors (trade and services), and wages in the productive sectors were boosted above the others. In some years, the location of the job within the government hierarchy (headquarters versus branch office) also mattered.

${ }^{10}$ Discussions with officials who used to administer the wage grid indicate that the process was taken very seriously and that administrators from various Soviet bloc countries compared notes and experiences. In this respect, the wage grid was an integral part of the centrally planned system.

${ }^{11}$ In order to understand this phenomenon, we examined the internal wage-setting practices in hundreds of firms with diverse ownership. We have also discussed this and other issues with representatives of employers, trade unions, and the Ministry of Labor and Social Affairs. Using the large firm-level data set collected by the Trexima Corporation, we found that as late as 1998 most state-owned and privatized firms still used modified wage grids from the communist days. The privatized enterprises were not required to pay according to any grid, and their adherence to it reflected inertia in (transaction costs related to changing) their compensation practices. The data and our discussions with the officials also indicate that in the mid 1990s foreign ownership was still concentrated in a few large companies (e.g., Skoda-Volkswagen, Tabak-Philip Morris, Czech Telecom), which may have changed compensation practices. However, most firms privatized to domestic owners continued their old personnel practices, usually employing personnel directors from the communist era. In contrast, the de novo private firms have been found to operate entirely outside the wage grid. Finally, government intervention in private-sector wage setting has been minimal, although loose wage controls were in effect intermittently from 1991 to 1995.
}

those in the public sector. The question that naturally arises is whether the rate of return on human capital under the transition grids matched or fell short of the market return provided by the new private firms.

\section{Data and Methodology}

\section{A. Data}

We use data from a retrospective questionnaire that was administered in December 1996 to 3,157 randomly selected households in all 76 districts of the Czech Republic. The questionnaire first asks for the wage and other characteristics of the jobs held in January 1989, the first month of the last year of the communist regime..$^{12}$ Because the "big bang" of liberalization started in Czechoslovakia on January 1, 1991, the questionnaire traces the characteristics of all the jobs held by the surveyed individuals between January 1991 and December 1996. As a result, we have continuous labor market histories for each individual during the entire 19911996 period. In particular, for each job we have the start wage and average hours of work, as well as the industry and ownership of the worker's firm. For the individuals employed in January 1991, we have also obtained information on wages and other characteristics at the start of the job held in January 1991. The starting dates of the jobs held in January 1991 span the entire 1948-1989 communist period, and we have used data from 1955 onward, while checking the robustness of our estimates by taking later starting points as well. ${ }^{13}$ In particular, in order to test if our results are sensitive to the inclusion of observations from the 1950s, 1960s, and 1970s, we have reestimated our models with subsamples that dropped observations on jobs that started before the 1980s, 1970s, and 1960s, respectively. As we report later, we found only negligible differences in the various estimates. Finally, for 1991-1996 we have collected information on each person's household and demographic characteristics, including changes in education.

The sample is representative of the 1996 population in its major demographic characteristics. It yields employment histories of 2,284 men who were employed for a minimum of 2 weeks during the period between January 1, 1991 and

\footnotetext{
12 The January 1989 date was selected as a point in time for which people were likely to remember their labor market characteristics, because 1989 was the year of the revolution that toppled the communist regime. See Münich et al. (1997) for a description of the survey and sample design as well as the descriptive statistics of the sample relative to the Labor Force Survey data.

${ }^{13}$ In fact, this question yields data on jobs that began as early as the 1940s: $0.3 \%$ of all the job starts reported occurred before 1951, 2.6\% occurred during 1951-1960, 5.5\% during 1961-1970, 9.2\% during 19711980, 18.9\% during 1981-1990, and 63.5\% during 1991-1996. We concluded that the very early data points went too far back in time to be reliable and that they might be confounded with the systemic changes that accompanied the communist takeover of 1948. As a result, we restricted our observations on job starts to those that occurred from 1955 onward, in as much as by 1955 the revolutionary period, nationalization, and currency reform that followed the communist coup d'état of 1948 were over and the centrally planned system was fully in place.
} 
December 31, 1996. For the "mature" communist period of 1955-1989, we use data on (a) the starting wages of 1,285 men who also held a job in January 1991 and (b) the cross section of wages of 1,955 men who were working during January 1989 (the first month of the last year of communism). For the transition period, we use cross-section observations on wages and job characteristics of the 1,639 men who worked in December 1996, as well as the job start information on 2,107 men during 1991-1996. The data hence permit us to estimate (a) cross-sectional earnings functions using data from ongoing jobs at one point in time near the end of communism (January 1989) and one point in time in mature transition (December 1996), and (b) earnings functions using a long (1955-1996) period of job start data under both regimes. The former estimates may be compared with Krueger and Pischke's (1995), Chase's (1998), and Flanagan's (1998) cross-sectional estimates; the latter ones provide a new longitudinal analysis during the communist and transition periods.

Different types of data sets have, by the nature of their design, different strengths and weaknesses. A weakness of retrospective data is the possibility of recall error. In our case, the problem is that individuals may not accurately remember their past wages. We expect this error to be relatively small, however, since wages set in the communist grid were clearly defined and did not change much through time. Moreover, the wages that we use from the distant past are starting wages on the very last job held under communism, which we expect to be more readily recalled than wages during an arbitrary past job. With respect to wages during the transition period (1991-1996), we expect them to be remembered fairly accurately, because there were few job changes: the average individual only held 1.6 jobs during this period.

By using the self-reported wage as a dependent variable rather than as a regressor, we avoid the usual problem of errors in variables with respect to the right-side variables. Nevertheless, we check the magnitude of the recall error by performing two tests. First, we estimate the rate of return to education by using different starting points in the past and find the estimates to be invariant to whether we start in the 1950s, 1960s, 1970s, or 1980s. Second, we compare our basic estimates of rates of return to education with: (1) Chase's (1998) estimates based on the 1984 and 1993 Czech household surveys, (2) Flanagan's (1998) estimates based on the 1988 Czech Microcensus and the 1996 Czech Survey of Economic Expectations and Attitudes, and (3) our estimates using a 1984 Czech firm-level survey. We find that these rates of return are similar to analogously calculated rates of return from our retrospective data.

Finally, there are two concerns related to the design of our retrospective data set. First, the sample is not fully representative of the communist era in that it is less likely to include individuals who were old men during the communist regime. In particular, we include in our sample those who were alive in 1996 and were not fully retired (i.e., worked at least two weeks) between 1991 and 1996. We hence exclude men who worked under communism and either fully retired before 1991 or died before 1996. ${ }^{14}$ Though this exclusion could be a problem if the individuals who retired or died had systematically different (e.g., lower) wages than others, there is no evidence that this was the case. Second, the communist era starting wage goes back further for individuals with long job tenure than for those with short job tenure. To the extent that these two types of individuals have systematically different unobserved characteristics that are correlated with some of the explanatory variables, the resulting time-varying coefficients have a duration bias. This concern is alleviated by our finding that parameter estimates are not affected in a material way by whether we put the starting point of the data in the 1950s (when the sample is arguably the least representative of the population of starting wages), 1960s, 1970s, or 1980s (when the sample is the most representative of starting wages for the labor force in the 1980s).

In appendix table A1, we present the 1989 and 1996 means and standard deviations of the variables that we use in estimating the cross-sectional earnings functions. In table $\mathrm{A} 2$, we report the corresponding information for the job start data during communism and the transition. As may be seen from the tables, the variables display sensible values and considerable variation both cross-sectionally and over time. Because manufacturing was the key part of the communist economy, over one-half of the men have apprenticeship education.

\section{B. Estimation Strategy}

In order to obtain estimates of the wage structure and returns to human capital at the end of communism (1989) and during the transition (1996), we first estimate the following augmented human capital earnings function with our 1989 and 1996 cross-sectional data:

$$
\ln W_{i}=\alpha_{0}+\alpha_{1} E_{i}+\alpha_{2} X_{i}+\alpha_{3} X_{i}^{2}+\alpha_{4} P_{i}+A_{i}^{\prime} \beta+\varepsilon_{i},
$$

where $\ln W_{i}$, the natural logarithm of the monthly earnings of individual $i$, is taken to be a function of the individual's educational attainment $\left(E_{i}\right)$, the number of years of his potential labor market experience $\left(X_{i}\right)$, a dummy variable for whether the individual worked in Prague $\left(P_{i}\right)$, and a set of ten industry dummy variables for the industry location of the individual's job $\left(A_{i}\right){ }^{15}$ The variables $A$ and $P$ control for

\footnotetext{
14 The retirement age for men was 60 years, but many retirees continued to work full or part time.

15 The monthly nominal earnings are meant to be net of payroll and income taxes. This is the most common way that the Czechs recall their salary, since both of these taxes are taken out before they receive their pay. However, about $25 \%$ of the respondents preferred to report their gross rather than net earnings. As a result, we have included as a regressor a dummy variable to control for this discrepancy in reporting. In addition,
} 
industry wage effects, compensating differentials, and agglomeration effects of the central city. We have also estimated the traditional Mincer equation (Mincer \& Polachek, 1974) by omitting $A$ and $P$ from equation (1), but the coefficients on education and experience were virtually the same. In what follows we report estimates of equation (1). ${ }^{16}$ We limit our analysis to workers with full-time jobs. In addition to examining all workers in 1989 and 1996, we estimate the regression separately for workers in three different ownership types: public administration and SOEs (henceforth "state"), privatized enterprises, and de novo firms.

An important stylized fact from the human capital literature is that the effect of education on wages often depends on how the education variable $E$ is measured. Unlike Krueger and Pischke (1995), Chase (1998), and Flanagan (1998), who have to impute $E$ from the highest educational degree completed, we are able to use and test the relative merit of three different specifications of $E$ : (i) the actual self-reported number of years of education (net of grade repetition), (ii) the highest level of attained schooling, and (iii) a combination of (i) and (ii). ${ }^{17}$

The number of years of education specification yields an estimate of a constant marginal rate of return on an additional year of schooling and reflects the approach advocated by Layard and Psacharopoulos (1974). The highest level of educational attainment by type of degree obtained allows the rate of return to vary across types of completed education and reflects the criticism of the assumption of a constant rate of return to each year of education (Heckman, Layne-Farrar, \& Todd, 1996). ${ }^{18}$ By including both of these variables, we are able to test between the competing specifications and see which one is better supported by the data in the communist and transitional contexts. Moreover, because we have data on actual years of schooling reported by the respondent, ${ }^{19}$ rather than years imputed by the researchers from the reported school attainment, we can test the sheepskin hypothesis that "wages rise faster with extra years of education when the extra year also conveys a certificate" (Hungerford and Solon, 1987). ${ }^{20}$

net earnings in some cases include benefits provided by the state, through the employer, for raising children. We have therefore also included a dummy variable to control for the cases when the reported earnings include child benefits.

${ }^{16}$ We have also tested for the effect of marital status in equation (1) and found it to be insignificant.

${ }^{17}$ We would like to thank Orley Ashenfelter for suggesting the combined specification to us.

${ }^{18}$ Our data permit us to estimate a specification with six categorical variables reflecting the highest degree attained: (1) junior high school (mandatory education of 9 years), (2) apprentices in 2 year programs, (3) apprentices in 3 year programs, (4) technical high school graduates and apprentices in 4 year programs who received the technical high school diploma, (5) academic high school graduates, and (6) university graduates and above.

${ }^{19}$ The respondents were asked not to report any years of repeated grades.

${ }^{20}$ The sheepskin effect refers to the fact that wages may not increase steadily with years of education within a given level of schooling but may jump up when a degree is received (see also Heckman et al., 1996). Using
As in most studies, our potential labor force experience variable $X$ is calculated as the individual's age minus the sum of the individual's years of schooling and the basic school enrollment age of 6 years. ${ }^{21}$ In order to provide a good sense of the nature of the experience-earnings profile, we use two alternative specifications of experience: the traditional quadratic one, and a spline function that fits the profile to three categories of years of experience.

Equation (1) enables us to compare cross-sectional estimates for late communism (1989) and mature transition (1996). For estimation covering the 1991-1996 period, we are able to include additional variables that capture important aspects of the transition and that are not relevant for the communist period. In particular, using our 1996 crosssection data, we estimate an equation that includes ownership dummy variables that capture whether the individual works in the state sector, for a privatized firm, or for a de novo firm. Finally, because we have data on wages at the start of jobs, we are also able to estimate continuous changes in the returns to human capital during the communist and transition periods. In order to capture these changes in a simple way, we extend equation (1) by estimating a time-varying-coefficient model by interacting the education $(E)$ and experience $\left(X\right.$ and $\left.X^{2}\right)$ variables with an annual time trend $\tau$, such that

$$
\alpha_{k}=\alpha_{k}^{t}+\tau \alpha_{k}^{\tau} \text { for } k=1,2,3,
$$

where subscripts $k=1,2$, and 3 denote the coefficients on $E, X$, and $X^{2}$, respectively, and superscript $t$ denotes the time-invariant and superscript $\tau$ the time-varying portion of the coefficient. We stratify the data by the pre- and postJanuary 1991 periods and estimate separate equations for the communist and transition periods, allowing intercepts to vary across the regressions..$^{22}$

It has become customary in the literature on earnings functions to correct for coefficient bias that may be brought about by the self-selection of a segment of nonrepresentative individuals (usually women) into the labor market. Because labor force participation rates of both women and men declined after the fall of communism, we tested for the presence of a selectivity bias in our sample, but we found it not to affect the coefficients of interest. ${ }^{23}$

U.S. data, Hungerford and Solon (1987) find significant discrete jumps in the return to education upon receiving a degree.

${ }^{21}$ The shortcoming of this variable is that it includes periods during which the individual may have been out of the labor market and acquired less labor force experience. This of course tends to be less of a problem in the case of men than women, who are likely to take long maternity leaves (Mincer \& Polachek, 1974; Mincer \& Ofek, 1982).

${ }^{22}$ Since the dependent variable is in nominal terms, we include annual dummies to control for changes in prices in all the models with timevarying coefficients. We have also tested for the validity of a model with higher than linearly time-varying coefficients, but we have not found strong support for this higher-order specification.

${ }^{23}$ Paukert (1995) finds that between 1989 and 1994 labor force participation rates of men and women (over 15 years of age) fell between 6 and 8 percentage points in the Czech Republic, Hungary, Poland, and Slovakia, and that the absolute decline was about the same for men and women 
Table 2.--Estimated Returns to a Year of Education, Cross-Sectional Evidence for the Czech Republic and Other Countries

\begin{tabular}{|c|c|c|c|c|c|}
\hline \multirow[b]{2}{*}{ Country } & \multirow[b]{2}{*}{ Reference Years } & \multicolumn{2}{|c|}{ Communism } & \multicolumn{2}{|c|}{ Transition } \\
\hline & & Men & Men \& Women & Men & Men \& Women \\
\hline \multicolumn{6}{|l|}{ CEE: } \\
\hline Czech Republic (1) & 1989, 1996 & 0.027 & & 0.058 & \\
\hline Czech Republic (2) & 1984,1993 & 0.024 & & 0.052 & \\
\hline Czech Republic (3) & 1989,1996 & 0.037 & & 0.045 & \\
\hline East Germany (4) & 1989,1991 & & 0.044 & & 0.041 \\
\hline East Germany (5) & 1988,1991 & & 0.077 & & 0.062 \\
\hline Poland (6) & 1987, 1992 & & 0.050 & & 0.070 \\
\hline Slovakia (2) & 1984,1993 & 0.028 & & 0.049 & \\
\hline \multicolumn{6}{|l|}{ CIS: } \\
\hline Russia (7) & 1991, 1994 & 0.031 & & 0.067 & \\
\hline \multicolumn{6}{|l|}{ Latin America: } \\
\hline Argentina (8) & 1989 & & & & 0.103 \\
\hline Chile (8) & 1989 & & & & 0.120 \\
\hline Mexico (8) & 1984 & & & & 0.141 \\
\hline Venezuela (8) & 1989 & & & & 0.084 \\
\hline \multicolumn{6}{|l|}{ Europe: } \\
\hline West Germany (8) & 1987 & & & & 0.049 \\
\hline West Germany (5) & 1988 & & & 0.075 & 0.077 \\
\hline Great Britain (8) & 1984 & & & & 0.068 \\
\hline Switzerland (8) & 1987 & & & & 0.079 \\
\hline United States (4) & 1989 & & & 0.085 & 0.093 \\
\hline
\end{tabular}

\section{Empirical Findings on Returns to Education}

We divide our discussion of the returns to education into four parts: In section IV A we present the returns to a year of education; in section IV B, the returns to an educational level; in section IV $\mathrm{C}$, the returns from a model that encompasses both years and levels to test for sheepskin effects; and in section IV D, the returns to the field of study within each level of schooling. All estimates control for heteroskedasticity using the White (1980) method.

\section{A. Returns to a Year of Education}

In table 2, we present our overall 1989 and 1996 crosssectional estimates of the rates of return to a year of education based on equation (1). ${ }^{24}$ For comparative purposes, we also report estimates from other studies in the Czech Republic and other selected countries. Our estimates suggest that in the last year of communism (1989), men's rate of return to a year of education was $2.7 \%$, and that it

in each country. Our survey provides us with a number of variables that can be used to impose exclusion restrictions in that they are likely to affect the respondent's labor force participation decision but not his wage. In particular, we derived Heckman's (1979) $\lambda$ by estimating a probit equation with the 1996 cross-section data, using as explanatory variables a marital status dummy, a dummy variable for the presence of children under 15 years of age in the household, the per capita household income minus the income of the respondent, a dummy variable for Prague, the district-level vacancy rates (the number of vacancies per working age inhabitant), and the respondent's age, age ${ }^{2}$, and education (in years). The estimation yields a positive and significant $\lambda$, but the estimated coefficients on education and experience remain unaffected by the correction procedure.

${ }^{24}$ The complete set of our estimates of equation (1) using the 1989 and 1996 cross-sectional data is presented in appendix table A3. rose to $5.8 \%$ by 1996 . The difference between the two coefficients is significant at the $1 \%$ significance test level. Our findings are in line with the cross-sectional estimates of 2.4\% for 1984 and 5.2\% for 1993 obtained for the Czech Republic by Chase (1998), indicating that the return on education was low under the communist wage grid and that it rose substantially during the transition. Because both studies depict a lower starting level and a more pronounced increase in the return on education than the increase from $3.7 \%$ in 1988 to $4.5 \%$ in 1996 found by Flanagan (1998), we have gone back to Flanagan's data to reestimate his equations and check for possible sources of the discrepancy between his and our results. In replicating Flanagan's (1998) results we noticed two important facts. First, Flanagan's 1998 data set (Microcensus 1988) uses only data on heads of households. This may over-represent older and more able individuals, and hence account for the higher rate of return on education reported by Flanagan for the communist period. Second, Flanagan's 1996 data set (the relatively small Survey of Economic Expectations and Attitudes) defines earnings as the sum of earned income and various social security benefits. Since the contribution of social security benefits to total income is more important for less educated workers, the construction of this dependent variable may explain the relatively low returns to education found in Flanagan's 1996 estimates.

The pattern of increased return on education is similar to that found by cross-sectional studies in other CEE countries, except for east Germany, in the early transition. As may be seen from table 2, within a few years after the start of the transition, the rates of return on a year of education in CEE 
Table 3.-Estimated Returns to a Year of EduCation

\begin{tabular}{|c|c|c|c|c|c|}
\hline \multirow[b]{2}{*}{ Reference Years } & \multirow{2}{*}{$\frac{\text { Communism }}{\text { All }}$} & \multicolumn{4}{|c|}{ Transition } \\
\hline & & All & State & Privatized & DeNovo \\
\hline \multicolumn{6}{|c|}{ A. Cross-Section Data $\uparrow$} \\
\hline 1989,1996 & $\begin{array}{l}0.0270 * * * \\
(0.004)\end{array}$ & $\begin{array}{l}0.0580^{* * * *} \\
(0.005)\end{array}$ & $\begin{array}{l}0.0560 * * * \\
(0.009)\end{array}$ & $\begin{array}{l}0.0650 * * * \\
(0.007)\end{array}$ & $\begin{array}{l}0.0610 \text { **** } \\
(0.010)\end{array}$ \\
\hline \multicolumn{6}{|c|}{ B. Time-Varying Coefficients $\ddagger$} \\
\hline $\begin{array}{l}\text { Annual change } \\
\quad(1955-1991 ; 1991-1996) \\
\text { Base as of January 1991 }\end{array}$ & $\begin{array}{c}-0.0004 \\
(0.001) \\
0.0170 \\
(0.010)\end{array}$ & $\begin{array}{l}0.0093 * * * \\
(0.002) \\
0.0220 * * * \\
(0.007)\end{array}$ & $\begin{array}{l}0.0098^{*} \\
(0.005) \\
0.0280^{* *} \\
(0.012)\end{array}$ & $\begin{array}{l}0.0104 * * * \\
(0.004) \\
0.0270 * * \\
(0.012)\end{array}$ & $\begin{array}{l}0.0077 * * * \\
(0.003) \\
0.0310^{* *} \\
(0.012)\end{array}$ \\
\hline
\end{tabular}

$¥$ Taken from Table A6. Based on job starts.

$*, * *, * * *$ Statistically significant at the $10 \%, 5 \%, 1 \%$ level. Standard errors in parentheses.

and Russia became similar to the rates in western Europe, but not as high as the rates in the United States and Latin America.

Whereas this may be the first place where the rates of return to education for all of these transition countries are presented together, the stylized fact drawn from table 2 is known. What is not yet known, however, is whether the rates of return to education vary with ownership. In the tables that follow, we report the rates of return by three important ownership categories: SOEs and public administration (State), privatized firms (Privatized), and private de novo firms (DeNovo). We are thus able to assess whether the new private entrepreneurs deviate from the communist era wage grid and reward human capital differently than their privatized and nonprivatized SOE counterparts. This is an important question in that postcommunist adjustments in the wage grid, reductions in government subsidies to the state sector, and the opening up of the economy to international competition induced important changes in the pay policies of the SOEs and privatized firms as well. Whether the returns to human capital are higher in the de novo, privatized, or public-sector firms depends on the relative magnitudes of these effects.

In panels $\mathrm{A}$ and $\mathrm{B}$ of table 3, we present estimated returns to a year of education using the cross-sectional and longitudinal data, respectively. In panel A, the 1996 crosssectional estimates by ownership suggest that the privatized firms provide the highest rate of return to a year of education $(6.5 \%)$, followed by the de novo firms $(6.1 \%)$ and the state $(5.6 \%){ }^{25}$ However, these results-based on 384 observations for state enterprises, 504 for privatized firms, and 604 for de novo firms - are not statistically different from one another, indicating no systematic difference in the education-based wage differentials across principal ownership forms. ${ }^{26}$

\footnotetext{
${ }^{25}$ The overall cross-sectional estimates for 1989 (2.7\%) and 1996 $(5.8 \%)$ are the same estimates presented in table 3.

${ }^{26}$ The lowest $P$-value is 0.43 for the difference between state and privatized firms. Flanagan (1998) found the returns to a year of education in 1996 to be lowest in the new private firms (5.8\%), highest in the privatized firms $(7.2 \%)$, and intermediate in the state section $(6.2 \%)$ However, since Flanagan does not report standard errors and relative tests
}

In panel $\mathrm{B}$ of table 3 , the time-varying coefficients are presented as the 1991 base and the annual change. The coefficient on the annual change (interaction term) is minuscule and insignificant during the communist period, indicating that under the communist grid the rate of return to a year of schooling remained constant over time at a mere $1.7 \%$. Moreover, a test of the difference between the point estimates from the longitudinal (1955-1989) and crosssectional (1989) data indicates that there was no statistically significant difference. In order to check if our estimates are sensitive to the starting date, we have also estimated the time-varying-coefficients model with observations going back to the 1960s, 1970s, and 1980s, respectively. We find that all three estimated coefficients on the interaction terms are insignificant and the base coefficients on education are in the range 0.15 to 0.21 and within 1 standard error of each other. Our results hence suggest that wage differentials based on education were low and stagnant under the decades of central planning, a finding that has not been documented before with microdata.

In contrast, our time-varying-coefficient estimates for 1991-1996 show that the estimated rate of return to a year of education increased by almost $1 \%$ a year during the transition. Privatized firms recorded the fastest rate of annual increase $(1.04 \%)$, followed by the state sector $(0.98 \%)$ and de novo firms $(0.77 \%)$, but the differences across ownership categories are not statistically significant. This finding hence complements the cross-sectional estimates by showing that the rate of return rose steadily during the transition period and that on average firms with different ownership remained competitive with respect to educationbased wage differentials.

of significance for these estimates, it is not possible to know if they are statistically different from one another or from our estimates either. We note that in Flanagan's data the years of education are imputed and include both men and women, which may account for the difference between his and our estimates. Finally, Flanagan's and our data also reveal lower payoffs to vocational education in the newly created private firms, but the difference in our data is not statistically significant. Again, Flanagan (1998) does not report formal tests for differences of coefficients, and we hence cannot establish if the two studies yield similar or dissimilar results. 
Table 4.-Estimated Returns by Level of Educational Attainment, Cross-Section Data $\dagger$

\begin{tabular}{|c|c|c|c|c|c|}
\hline \multirow[b]{2}{*}{ Level } & \multirow{2}{*}{$\frac{\text { Communism (1989) }}{\text { All }}$} & \multicolumn{4}{|c|}{ Transition (1996) } \\
\hline & & All & State & Privatized & DeNovo \\
\hline \multicolumn{6}{|c|}{ A. Level of Attainment } \\
\hline Apprentices (2 years) & $\begin{array}{c}0.063 \\
(0.051)\end{array}$ & $\begin{array}{c}0.094 \\
(0.057)\end{array}$ & $\begin{array}{c}0.129 \\
(0.121)\end{array}$ & $\begin{array}{c}0.114^{*} \\
(0.065)\end{array}$ & $\begin{array}{c}0.101 \\
(0.137)\end{array}$ \\
\hline Apprentices (3 years) & $\begin{array}{l}0.077 * * \\
(0.037)\end{array}$ & $\begin{array}{l}0.112 * * \\
(0.049)\end{array}$ & $\begin{array}{c}0.097 \\
(0.105)\end{array}$ & $\begin{array}{l}0.156^{* * * *} \\
(0.058)\end{array}$ & $\begin{array}{c}0.065 \\
(0.115)\end{array}$ \\
\hline Vocational HS (4 years) & $\begin{array}{l}0.127 * * * \\
(0.040)\end{array}$ & $\begin{array}{l}0.294^{* * * *} \\
(0.050)\end{array}$ & $\begin{array}{l}0.323 * * * \\
(0.105)\end{array}$ & $\begin{array}{l}0.327 * * * \\
(0.058)\end{array}$ & $\begin{array}{l}0.249 * * \\
(0.118)\end{array}$ \\
\hline Academic HS (4 years) & $\begin{array}{c}0.135^{*} \\
(0.081)\end{array}$ & $\begin{array}{l}0.351 \text { *** } \\
(0.107)\end{array}$ & $\begin{array}{l}0.401 * * * \\
(0.142)\end{array}$ & $\begin{array}{c}0.266 \\
(0.164)\end{array}$ & $\begin{array}{c}0.342 \\
(0.309)\end{array}$ \\
\hline University & $\begin{array}{l}0.283^{* * * *} \\
(0.045)\end{array}$ & $\begin{array}{l}0.544 * * * \\
(0.059)\end{array}$ & $\begin{array}{l}0.476^{* * * *} \\
(0.115)\end{array}$ & $\begin{array}{l}0.673 * * * \\
(0.072)\end{array}$ & $\begin{array}{l}0.599 * * * \\
(0.133)\end{array}$ \\
\hline \multicolumn{6}{|c|}{ B: Calculated Annual Returns within Attainment Level $\ddagger$} \\
\hline Apprentices (2 years) & 0.032 & 0.048 & 0.067 & 0.059 & 0.052 \\
\hline Apprentices (3 years) & 0.026 & 0.038 & 0.033 & 0.053 & 0.022 \\
\hline Vocational HS (4 years) & 0.032 & 0.076 & 0.084 & 0.085 & 0.064 \\
\hline Academic HS (4 years) & 0.034 & 0.092 & 0.105 & 0.069 & 0.089 \\
\hline University & 0.044 & 0.076 & 0.040 & 0.127 & 0.102 \\
\hline
\end{tabular}

\section{B. Estimates Based on Attained Levels of Education}

In panel A of table 4, we report 1989 and 1996 crosssectional estimates for several different levels of schooling, relative to the mandatory junior high school. (The full set of parameters is presented in table A4.) We use these estimates to calculate the annual returns to a year of education within each completed category of schooling (panel B). ${ }^{27}$ The time-varying coefficients are presented in table 5, and the full set of parameters is reported in table A7.

As may be seen from the first column of table 4 , at the end of the communist regime the earnings differentials between different types of schooling were small. For example, a university-educated man earned just about $28 \%$ more than an otherwise identical man with a junior high school education. Similarly, men with a vocational high school degree earned $13 \%$ more than their counterparts with a junior high school education. Finally, the earnings of men with a two-year apprenticeship and junior high school were about the same.

By 1996 the returns to higher levels of education increased dramatically (column 2 of table 4). A universityeducated man earned $72 \%$ more (coefficient of 0.544 ) than his counterpart with junior high school education. ${ }^{28}$ The difference between the 1989 and 1996 coefficients on uni-

\footnotetext{
${ }^{27}$ Each of the four schooling levels below university level represents a direct path from junior high school (the mandatory level of education). Hence, the annual return to a year of education within these levels of schooling relative to junior high school $\left(r_{s}\right)$ is calculated as the $n^{\text {th }}$ root of the rate of return to the schooling level $\left(R_{s}\right)$, where $s$ represents the level of schooling and $n$ represents the number of years of education in each level: $r_{s}=\left(R_{s}\right)^{1 / n}$. However, the return to a year of university education represents a return above either academic or vocational high school, and hence it is calculated as $r_{u}=\left(R_{u}-\bar{R}_{\mathrm{hs}}\right)^{1 / n}$, where the bar denotes the average value.

28 The return is calculated as $\exp ($ coefficient $)-1$; in this case $\exp (0.544)-1=72 \%$.
}

versity education is significantly different at the 0.01 confidence level. We also find that the difference between 1996 and 1989 in the returns to a vocational high school education is highly significant and that the percentage increase in this return is the largest among all the education levels. On the other hand, the return to an apprenticeship did not change significantly over time.

Examining the 1996 returns in table 4 by firm ownership, one observes that privatized firms are the only ones valuing apprenticeship over junior high school education and that academic high school education is significantly valued only in the state sector. However, all firm types pay more to men with vocational or university degrees. The estimated coefficient on university education is highest in privatized firms (0.673), followed by de novo firms (0.599) and state enterprises and public administration (0.476). The difference between the university coefficients for privatized firms and state enterprises approaches statistical significance ( $p$-value of 0.14 ), but in all other pairwise comparisons across ownership categories, one cannot reject the hypothesis of equality of returns. Our estimates hence indicate that firms with different ownership display tendencies to remunerate different types of human capital differently but, as in the case of returns to a year of schooling, these differences are not statistically significant.

As may be seen from panel $B$ of table 4, in late communism the calculated return to a year of education was almost the same at all levels of schooling, except possibly the university. Yet, by 1996 the return to a year of academic or vocational high school education rose above the return to a year of apprenticeship, thus providing support for the hypothesis of uneven returns across educational categories. The estimates by ownership appear to amplify this finding. 
Table 5.-Estimated Returns by Level of Educational Attainment $\dagger$ (Time-Varying-Coefficients Model)

\begin{tabular}{|c|c|c|c|c|c|}
\hline & \multirow{2}{*}{$\begin{array}{l}\text { Communism } \\
\frac{(1955-1989)}{\text { All }}\end{array}$} & \multicolumn{4}{|c|}{ Transition (1991-1996) } \\
\hline & & All & State & Privatized & DeNovo \\
\hline Apprentice (2 years) & $\begin{array}{c}0.057 \\
(0.101)\end{array}$ & $\begin{array}{c}-0.078 \\
(0.106)\end{array}$ & $\begin{array}{c}0.153 \\
(0.167)\end{array}$ & $\begin{array}{c}0.154 \\
(0.156)\end{array}$ & $\begin{array}{r}-0.066 \\
(0.164)\end{array}$ \\
\hline Apprentice $(2$ years $) \cdot t$ & n.a. & $\begin{array}{l}0.079 * * \\
(0.031)\end{array}$ & $\begin{array}{c}0.024 \\
(0.051)\end{array}$ & $\begin{array}{c}0.061^{*} \\
(0.034)\end{array}$ & $\begin{array}{c}0.062 \\
(0.062)\end{array}$ \\
\hline Apprentice (3 years) & $\begin{array}{c}0.069 \\
(0.075)\end{array}$ & $\begin{array}{c}0.049 \\
(0.069)\end{array}$ & $\begin{array}{c}0.095 \\
(0.112)\end{array}$ & $\begin{array}{c}0.118 \\
(0.103)\end{array}$ & $\begin{array}{c}0.087 \\
(0.078)\end{array}$ \\
\hline Apprentice $(3$ years $) \cdot t$ & $\begin{array}{c}0.000 \\
(0.005)\end{array}$ & $\begin{array}{l}0.053 * * \\
(0.021)\end{array}$ & $\begin{array}{l}0.065^{* * * *} \\
(0.022)\end{array}$ & $\begin{array}{c}0.042 * \\
(0.022)\end{array}$ & $\begin{array}{l}0.032 * * \\
(0.015)\end{array}$ \\
\hline Vocational HS (4 years) & $\begin{array}{c}0.056 \\
(0.082)\end{array}$ & $\begin{array}{c}0.051 \\
(0.074)\end{array}$ & $\begin{array}{c}0.059 \\
(0.124)\end{array}$ & $\begin{array}{c}0.203^{*} \\
(0.117)\end{array}$ & $\begin{array}{l}0.183 * * \\
(0.091)\end{array}$ \\
\hline Vocational HS (4 years) $\cdot t$ & $\begin{array}{r}-0.001 \\
(0.006)\end{array}$ & $\begin{array}{l}0.077 * * * \\
(0.022)\end{array}$ & $\begin{array}{l}0.102 * * * \\
(0.032)\end{array}$ & $\begin{array}{l}0.047^{* *} \\
(0.022)\end{array}$ & $\begin{array}{c}0.032^{*} \\
(0.019)\end{array}$ \\
\hline Academic HS (4 years) & $\begin{array}{c}0.338 * \\
(0.178)\end{array}$ & $\begin{array}{c}0.090 \\
(0.113)\end{array}$ & $\begin{array}{c}0.299 \\
(0.186)\end{array}$ & $\begin{array}{c}0.059 \\
(0.240)\end{array}$ & $\begin{array}{c}0.013 \\
(0.186)\end{array}$ \\
\hline Academic HS (4 years) $\cdot t$ & $\begin{array}{c}0.010 \\
(0.011)\end{array}$ & $\begin{array}{c}0.033 \\
(0.034)\end{array}$ & $\begin{array}{c}0.037 \\
(0.056)\end{array}$ & $\begin{array}{c}0.104 * \\
(0.056)\end{array}$ & $\begin{array}{c}0.032 \\
(0.053)\end{array}$ \\
\hline University & $\begin{array}{l}0.179 * * \\
(0.089)\end{array}$ & $\begin{array}{l}0.268 \text { *** } \\
(0.082)\end{array}$ & $\begin{array}{l}0.330 * * \\
(0.133)\end{array}$ & $\begin{array}{l}0.405 * * * \\
(0.127)\end{array}$ & $\begin{array}{l}0.316 \text { *** } \\
(0.112)\end{array}$ \\
\hline University $\cdot t$ & $\begin{array}{c}-0.005 \\
(0.007)\end{array}$ & $\begin{array}{l}0.100 * * * \\
(0.025)\end{array}$ & $\begin{array}{l}0.117 \text { *** } \\
(0.041)\end{array}$ & $\begin{array}{l}0.076^{* * *} * \\
(0.026)\end{array}$ & $\begin{array}{l}0.099 \text { *** } \\
(0.025)\end{array}$ \\
\hline
\end{tabular}

\footnotetext{
$*, * *, * * *$ Statistically significant at the $10 \%, 5 \%, 1 \%$ level. Standard errors in parentheses.
}

When we estimate the time-varying-coefficient model on 1955-1989 data, we find no change in the returns to educational attainment over time (table 5). The small differences in returns among the various levels of education are also analogous to those based on the 1989 cross-section data. ${ }^{29}$ The 1991-1996 estimates for all workers indicate that during the transition the rate of return on education rose significantly in all categories except for academic high school. The ownership-specific, time-varying estimates complement the cross-sectional estimates in table 4 by showing that the increase in the rate of return on 2 year apprenticeship has been driven by privatized firms. Moreover, whereas privatized and de novo firms provided a significant rate of return on vocational training already in 1991, the state sector registers faster growth in this return during 1991-1996, especially compared to de novo firms. Finally, the return for university education was also growing most rapidly in the state sector.

Overall, our findings from tables 4 and 5 indicate that education-related wage differentials were small and stagnant under communism. Market forces have increased wages for those with vocational high school and university education, but the gains were nil for those with lower education. The results based on firm ownership indicate that university education appears to be valued by all firm types, but most by the privatized firms and least by the state enterprises.

\footnotetext{
29 The 1955-1990 results also indicate that men with academic high school and university degrees had higher starting wages than others and that the wages of high school and university graduates were not statistically different from each other ( $P$-value of 0.96$)$.
}

\section{Regressions with Years and Levels of Education}

Screening theories of education suggest that diplomas serve as a signal of higher productivity and one should therefore expect diplomas to be rewarded in the labor market. Various studies using U.S. data test for sheepskin effects by estimating the difference in wages of individuals with and without a diploma, conditional on years of schooling (see, e.g., Hungerford \& Solon, 1987; Card \& Krueger, 1992; and Jaeger \& Page, 1996). Except for Jaeger and Page's (1996) study, however, the U.S. estimates are based on data that do not have information on the highest degree attained by an individual and therefore have to impute the level attained from the usual number of years it takes to complete a given degree. In contrast, researchers of transition economies usually have only information on the highest degree attained and must impute the number of years of schooling of an individual by using the usual number of years it takes to complete a degree. To the extent that individuals obtain a diploma with more or fewer years of study, estimates of sheepskin effects in the U.S. and returns to a year of education in the transition countries are biased. We are fortunate to have information on both the individual's reported years of education (net of any repeated grades) and the highest degree attained. We can thus obtain unbiased estimates of the sheepskin effect and also test for the bias using imputed versus actual years of schooling. We also show a new way of testing for the sheepskin effect by estimating returns to years of study that lead to a degree and those that do not. 
TABLE 6.-SHEEPSKIN EFFECTS

\begin{tabular}{|c|c|c|c|c|c|}
\hline & \multirow{2}{*}{$\begin{array}{c}\begin{array}{c}\text { Communism } \\
(1989)\end{array} \\
\text { All }\end{array}$} & \multicolumn{4}{|c|}{ Transition (1996) } \\
\hline & & All & State & Privatized & DeNovo \\
\hline \multirow[t]{2}{*}{ Years of education } & 0.006 & $0.020 * *$ & $0.042 * * *$ & 0.002 & 0.000 \\
\hline & $(0.007)$ & $(0.009)$ & $(0.016)$ & $(0.013)$ & $(0.018)$ \\
\hline \multirow[t]{2}{*}{ Apprentices (1-2 years) } & 0.052 & 0.058 & 0.057 & 0.110 & 0.101 \\
\hline & $(0.054)$ & $(0.061)$ & $(0.119)$ & $(0.071)$ & $(0.142)$ \\
\hline \multirow[t]{2}{*}{ Apprentices (3-4 years) } & 0.060 & 0.056 & 0.001 & $0.150 * *$ & 0.066 \\
\hline & $(0.043)$ & $(0.055)$ & $(0.106)$ & $(0.067)$ & $(0.129)$ \\
\hline \multirow[t]{2}{*}{ Vocational HS (4 years) } & $0.100^{*}$ & $0.209 * * *$ & 0.176 & $0.318^{* * *}$ & $0.250 *$ \\
\hline & $(0.052)$ & $(0.062)$ & $(0.113)$ & $(0.077)$ & $(0.143)$ \\
\hline \multirow[t]{2}{*}{ Academic HS (4 years) } & 0.108 & $0.271^{* *}$ & $0.247 *$ & 0.257 & 0.343 \\
\hline & $(0.088)$ & $(0.112)$ & $(0.137)$ & $(0.170)$ & $(0.316)$ \\
\hline \multirow[t]{2}{*}{ University } & $0.229 * * *$ & $0.367 * * *$ & 0.144 & $0.655^{* * *}$ & $0.601 * * *$ \\
\hline & $(0.078)$ & $(0.093)$ & $(0.155)$ & $(0.132)$ & $(0.199)$ \\
\hline
\end{tabular}

Note: The regressions also include control dummies for child benefits, taxes, and nine industries.

$*, * *, * *$ Statistically significant at the $10 \%, 5 \%, 1 \%$ level. Standard errors in parentheses.

Table 7.-Estimated Returns for Imputed Years and Additional Years of Schooling†

\begin{tabular}{|c|c|c|c|c|}
\hline & \multicolumn{2}{|c|}{ Communism (1989) } & \multicolumn{2}{|c|}{ Transition (1996) } \\
\hline & (1) & (2) & (3) & (4) \\
\hline Imputed years of education & $\begin{array}{l}0.033^{* * * *} \\
(0.004)\end{array}$ & $\begin{array}{l}0.032^{* * * *} \\
(0.004)\end{array}$ & $\begin{array}{l}0.066^{* * *} \\
(0.006)\end{array}$ & $\begin{array}{l}0.065^{* * * *} \\
(0.006)\end{array}$ \\
\hline An additional year of schooling above any degree $\dagger$ & - & $\begin{array}{l}0.020 * * \\
(0.008)\end{array}$ & - & $\begin{array}{l}0.034 * * * \\
(0.012)\end{array}$ \\
\hline
\end{tabular}

means the number of years above the highest level of attainment which do not lead to a degree. All the regressions also include control dummies for child benefits, taxes, and nine industries.

$*, * *, * * *$ Statistically significant at the $10 \%, 5 \%, 1 \%$ level. Standard errors in parentheses

In table 6, we present the coefficients for a specification that includes years of education (net of grade repetition) and dummy variables for highest degree attained, estimated from the 1989 and 1996 cross-sectional data and controlling for the variables listed in equation (1). In both years, we find sheepskin effects for higher levels of education-vocational high school and university degrees in 1989, and these two degrees plus the academic high school diploma in 1996. We also find an overall effect associated with completing degrees in that we reject (at 1\% in 1996 and $11 \%$ in 1989) the hypothesis that the coefficients on the five educational levels are jointly zero. The estimated coefficients on higher education also become greater over time, but $F$-tests on pairwise differences of the coefficients between 1989 and 1996 do not find any of them to be statistically significant. Examining the sheepskin effect by firm ownership during the transition, we find that the privatized and de novo firms place more importance on diplomas than the state sector and that the state sector is the only owner that values years of education. ${ }^{30}$

Since many other studies, including Krueger and Pischke (1995), Flanagan (1998), and Chase (1998), had to impute the information on years of education from data on attainment, we have taken advantage of the dual reporting in our data and reestimated our regressions with the imputed years

\footnotetext{
${ }^{30}$ The coefficient differences between state and privatized firms and between state and de novo firms are found to be statistically significant at $5 \%$ and $9 \%$, respectively.
}

of education in order to assess the magnitude of the errorsin-variables bias of this indirect, but commonly used, measure. Normally, the imputed years of education would generate a downward bias that is associated with errors in variables. However, in our case the imputed years of education may generate an upward bias because the measure underestimates the number of years of schooling for people that study for additional years without obtaining a degree. Indeed, the coefficient on imputed years of schooling (the first row of table 7) is higher than the coefficient on actual years attended (table 3 ) for both communism ( 0.033 versus 0.027 ) and transition (0.066 versus 0.058$)$. The associated standard errors are sufficiently large, however, not to permit us to reject the hypothesis that in both periods the coefficients on imputed and reported years of education are not statistically different from one another. ${ }^{31}$ The downward and upward biases hence just about cancel one another out.

We also test for the sheepskin effect using data on years of education and attained degree. In particular, we test the hypothesis that years of education that lead to a degree have a higher payoff than those that do not. To implement the test, we use our information on the total number of reported years of education and the highest degree obtained, together with the knowledge of the usual number of years needed to obtain a given degree. Using this information, we impute the number of years of education used for (a) obtaining the

\footnotetext{
${ }^{31}$ The $P$-values for the $F$-tests are 0.560 in 1989 and 0.558 for 1996 .
} 
Table 8.-Cross-Sectional Estimates of Returns to a Year of Labor Market Experience $\dagger$

\begin{tabular}{|c|c|c|c|c|c|}
\hline & \multirow{2}{*}{$\frac{\text { Communism (1989) }}{\text { All }}$} & \multicolumn{4}{|c|}{ Transition (1996) } \\
\hline & & All & State & Privatized & DeNovo \\
\hline Experience & $\begin{array}{l}0.021 * * * \\
(0.003)\end{array}$ & $\begin{array}{l}0.021 * * * \\
(0.005)\end{array}$ & $\begin{array}{l}0.015^{* *} \\
(0.006)\end{array}$ & $\begin{array}{l}0.022 \text { *** } \\
(0.007)\end{array}$ & $\begin{array}{l}0.030 * * * \\
(0.004)\end{array}$ \\
\hline Experience $^{2}$ & $\begin{array}{l}-0.0004 * * * \\
(0.0001)\end{array}$ & $\begin{array}{c}-0.0004 * * * \\
(0.0001)\end{array}$ & $\begin{array}{c}-0.0003^{* * * *} \\
(0.0001)\end{array}$ & $\begin{array}{c}-0.0004 * * \\
(0.0002)\end{array}$ & $\begin{array}{c}-0.0007 * * * \\
(0.0001)\end{array}$ \\
\hline
\end{tabular}

$\dagger$ Taken from Table A3, years of education.
$*, * *, * * *$ Statistically significant at the $10 \%, 5 \%, 1 \%$ level. Standard errors in parentheses.

most advanced degree and (b) additional study not resulting in a degree. In columns (2) and (4) of table 7, we show the coefficients from a specification that enters these two measures as explanatory variables in the standard regression of equation (1). In both 1989 and 1996 the coefficients on the additional years of study are significantly different from 0 but smaller than the coefficients on the imputed years leading to a degree. The $F$-tests indicate that the difference in the coefficients on imputed versus additional years is significantly different from 0 in 1996 but not in 1989. ${ }^{32}$

Overall, our results point to the presence of a sheepskin effect, and the effect is more pronounced at higher educational levels, and during the transition than under communism. They also caution that studies that impute years of education from educational attainment and do not control for dropping out or for repetition overestimate the rate of return on education. ${ }^{33}$

\section{Returns to a Field of Study}

Our data also permit us to estimate the returns to a field of study for a given level of education and assess whether there was a shift in these returns from the communist to the market system. As we show in table A5, there is no statistically significant change in the returns to the different fields of study from 1989 to 1996 for men who only attained an apprentice education. For men whose highest level of education was vocational high school, most of the coefficients on the fields of study rose between 15 and 25 percentage points from 1989 to 1996. Men trained in business and trade services gained relatively more over this period, as did men in manufacturing and electrical engineering. Those trained in law, teaching, and "other social branches" saw no change in their returns. For the university-educated men all the coefficients more or less doubled in size between 1989 and 1996. The high outlier is law, where returns rose by a factor of almost 3. On the low end, the returns of those trained in health, teaching, and "other social branches," financed from the state budget, did not change over time. Our data hence reveal important shifts in the returns to fields of study. As

\footnotetext{
${ }^{32}$ We have $F(1,1934)=1.36, P$-value 0.243 for 1989 ; and $F(1,1610)=$ 5.72, $P$-value 0.017 for 1996 .

${ }^{33}$ The actual coefficients reported from other studies in table 2 are not necessarily higher than ours. As mentioned earlier, Flanagan's (1996) estimates come from data that, by construction of the earnings variable, produce a downward bias. The coefficients from the other studies refer to earlier years in the 1990s when the return on education was still low.
}

expected, in business and trade services education has become more highly rewarded. Similarly, the higher rate of return for university-educated lawyers is consistent with the increase in demand for legal services during the process of privatization and increased reliance on legal institutions.

\section{Returns to Experience}

We explore the returns to experience in the two regimes with our cross-section and longitudinal data and with the information provided by the wage grids. In table 8 , we present the coefficients and standard errors of the experience and experience squared terms estimated with the 1989 and 1996 cross-sectional data. ${ }^{34}$ Focusing on the first two columns for all workers, we find the coefficients are statistically significant and within the standard range. We test the differences in these coefficients from 1989 to 1996 and find that the experience-earnings profile did not change from communism to the transition, peaking around 26 years in both regimes.

On the other hand, our estimates by ownership categories (columns 3-5 of table 8) show marked differences in experience-based wage setting across the three types of ownership. The wage experience profile is flattest in the state sector, more concave in privatized firms, and most concave in de novo firms. The coefficients on the experience terms for the de novo firms are statistically different from those for the state and close to being statistically different from those of privatized firms in both specifications. Men's wage-experience profiles begin steeper in de novo firms than in the state sector, but they are also more concave and have an earlier turning point. De novo firms hence pay higher returns on a year of experience to employees with low experience (recent entrants into the labor market) and lower returns to men near retirement age. ${ }^{35}$

\footnotetext{
${ }^{34}$ These results are based on the regression where education is measured as actual years of schooling (table A3). We also estimated experience coefficients in a regression with education measured as level of attainment (table A4) and found that there was no statistically significant difference in the estimated experience-earnings profiles. The $F$-test statistics are $F(2$, $3547)=0.07$ for the 1989-versus-1996 comparison based on the specification with years of education, and $F(2,3539)=0.28$ for the comparison based on the specification with levels of education. To save space, we only report one set of experience coefficients.

${ }^{35}$ In order to check the robustness of these findings, we have also reestimated the three ownership-specific equations with all coefficients, except those on education, experience, and experience squared, constrained to be equal. The resulting estimates are very similar to those
} 
The similarity of the estimated wage-experience profile under communism, in the transition economy, and in the market economies has led us to collect data on wage grids in a number of periods of the communist regime, as well as the transition, and analyze them more systematically. The search was surprisingly laborious, but we were able to obtain various wage grids, from 1954 to 1998 . The wageexperience profiles given by these grids are presented for 1954, 1979, 1985-1989, and 1998 in figure 1A-D as the "Tariff based profiles." We note that we could not find grids pertaining to the same reference group over time, and the grids hence should not be compared longitudinally. For example, the 1954 grid is for agricultural workers, the 1979 grid is for workers in forestry, the 1985-1989 grid is for white collar workers, and the 1998 grid is for all workers in SOEs, public administration, and privatized SOEs. As we noted in section I, the method for structuring the grid also changed over time; for example, in the earlier years it had an industrial component, and in later years it did not. Nevertheless, the grids permit us to discern that in all years the wage-experience profiles are piecewise linearly concave and have a flat region in the latter part of the profile. Hence, while ideology led the planners to impose narrow educationrelated wage differentials and cap the experience-earnings profile, they built into the grid enough wage progression in the early years of experience to generate a Mincerian-type concave profile.

Given the nature of all the grids, we fit the quadratic Mincerian earnings-experience function to the data of the five grids dating from 1954 to 1998 . These coefficients are reported in table 9 and also plotted in figure 1A-D. We see in figure 1 that the quadratic function fits the wage grids fairly well, and better in some years (e.g., 1998) than in others (e.g., 1985). The goodness of fit is particularly high in the 1998 grid because of its fine gradation of earnings with seniority. The plots and the coefficients also show that the slope and concavity of the wage-experience profile in agriculture were fairly small, whereas the profile was much steeper for all workers in 1998. We note that the coefficients in table 9 for the 1998 wage grid are very similar to the coefficients from our data for all workers in 1996. It hence appears that the experience-earnings profile in the grid became steeper over time, but since the grids in the earlier

reported in table 8 . We have also estimated spline experience-earnings profiles, where the splines capture three 10-year experience intervals from the start of one's career. Although the spline functions generate similar results to the coefficients on the quadratic experience profiles, in that they are similar in 1989 and 1996 for all workers, they highlight a greater decline in 1996 than in 1989 in the returns to workers with more than 30 years of experience; it is clear that it is the de novo firms that are driving this steeper slope for the $30+$ segment. As we noted in the paragraph above, this corresponds to the greater concavity of the wage-experience profile in the de novo firms. And as with the quadratic experience estimates described above, the spline profile (at least for men with 30 years or less of experience) in de novo firms is clearly above that of the privatized firms and state sector, which are very similar. Estimating spline functions at other than 10 year intervals did not fundamentally change the results.
TABle 9.-PARAmeters From Fitting the WaGe Grid WITH a QUAdRATIC WAGE-EXPERIENCE FunCtION

\begin{tabular}{llccc}
\hline \hline \multirow{2}{*}{ Year (s) } & \multirow{2}{*}{ Occupation } & \multicolumn{2}{c}{ Parameter } & \\
\cline { 3 - 4 } & Exper. & Exper. & \multirow{2}{*}{ Source } \\
\hline 1954 & Agriculture & 0.016 & -0.0030 & $*$ \\
1973 & Industry & 0.017 & -0.0004 & $\dagger$ \\
1979 & Forestry & 0.024 & -0.0004 & $\ddagger$ \\
1982 & Manual workers & 0.032 & -0.0006 & $\S$ \\
$1985-1989$ & White collar & 0.039 & -0.0006 & $* *$ \\
1998 & SOEs, publ. admin. & 0.023 & -0.0003 & $\dagger \dagger$ \\
\hline
\end{tabular}

*Ministry of Agriculture (1952)

Ministry of Industry (1973).

Ministry of Agriculture (1979)

\$inistry of Defense (1982)

**Ministry of Labor and Social Affairs $(1985,1986)$

$\dagger \uparrow$ Ministry of Labor and Social Affairs (1998)

years apply to different types of narrowly defined workers, we cannot formally draw this conclusion. Rather, we turn to our sample to test whether the experience-earnings profile changed over the communist period.

The time-varying estimates of the coefficients on experience (table 10) permit us to provide the first assessment of the extent to which the concavity of the experience-earnings profiles changes over time within the communist and transition periods. Although the coefficients on experience interacted with time are all positive and those on experience squared interacted with time are all negative, suggesting that the profile is becoming steeper and more concave over time, only the coefficient on experience interacted with time for the communist period in the specification based on education levels (panel B) is marginally statistically significant (at $10 \%$ test level). In this latter specification, an $F$-test on the joint significance of experience interacted with time and experience squared interacted with time also indicates that at $5 \%$ significance test level one cannot reject the hypothesis that the slope of the profile was changing during 19551989. In contrast, joint $F$-tests performed on the overall estimates in panel A for 1955-1990 and panels A and B for 1991-1996 suggest that the profile was not changing significantly over time. Moreover, tests of equality of experience-related coefficients between the 1955-1990 and 1991-1996 periods indicate that one cannot reject the hypothesis of equality of the evolution of the experience profile during the two periods. ${ }^{36}$ We hence conclude that the experience-earnings profile for all workers under communism approximated the Mincerian human capital earnings function; there is weak evidence that the profile was altered during communism, but its evolution was not altered during the first 6 years of the transition.

The time-varying estimates based on firm ownership (columns 3-5 of table 10) confirm that during 1991-1996 the wage-experience profile is concave in all three types of ownership categories and that it does not change signifi-

\footnotetext{
${ }^{36}$ The relevant $F$-statistic is $F(4,3266)=0.29$ for the model based on years of education and 0.28 for the model based on levels of educational attainment.
} 
Table 10.-Time-Varying Estimates of Returns to a Year of Labor Market ExPerience

\begin{tabular}{|c|c|c|c|c|c|}
\hline & \multirow{2}{*}{$\begin{array}{c}\begin{array}{c}\text { Communism } \\
(1955-1989)\end{array} \\
\text { All }\end{array}$} & \multicolumn{4}{|c|}{ Transition (1991-1996) } \\
\hline & & All & SOE & Privatized & DeNovo \\
\hline \multicolumn{6}{|c|}{ A. Education in years $\dagger$} \\
\hline Experience & $\begin{array}{l}0.0236 * * * \\
(0.005)\end{array}$ & $\begin{array}{l}0.0285 * * * \\
(0.005)\end{array}$ & $\begin{array}{l}0.0349 * * * \\
(0.007)\end{array}$ & $\begin{array}{l}0.0256 * * * \\
(0.009)\end{array}$ & $\begin{array}{l}0.0283 * * * \\
(0.006)\end{array}$ \\
\hline Experience $\cdot t$ & $\begin{array}{c}0.0007 \\
(0.0005)\end{array}$ & $\begin{array}{c}0.0017 \\
(0.0014)\end{array}$ & $\begin{array}{c}0.0018 \\
(0.003)\end{array}$ & $\begin{array}{c}0.0012 \\
(0.003)\end{array}$ & $\begin{array}{c}0.0012 \\
(0.002)\end{array}$ \\
\hline Experience $^{2}$ & $\begin{array}{c}-0.0005 * * * \\
(0.0002)\end{array}$ & $\begin{array}{c}-0.0006^{* * * *} \\
(0.0001)\end{array}$ & $\begin{array}{c}-0.0008^{* * * *} \\
(0.0001)\end{array}$ & $\begin{array}{c}-0.0006 * * \\
(0.0002)\end{array}$ & $\begin{array}{c}-0.0007 * * * \\
(0.0001)\end{array}$ \\
\hline Experience $^{2} \cdot t$ & $\begin{array}{c}-0.000004 \\
(0.00002)\end{array}$ & $\begin{array}{c}-0.00004 \\
(0.00004)\end{array}$ & $\begin{array}{c}0.00003 \\
(0.00006)\end{array}$ & $\begin{array}{r}-0.00002 \\
(0.00007)\end{array}$ & $\begin{array}{c}0.00000 \\
(0.00004)\end{array}$ \\
\hline \multicolumn{6}{|c|}{ B. Education Levels } \\
\hline Experience & $\begin{array}{l}0.0244 * * * \\
(0.006)\end{array}$ & $\begin{array}{l}0.0291 \text { **** } \\
(0.005)\end{array}$ & $\begin{array}{l}0.0411 * * * \\
(0.006)\end{array}$ & $\begin{array}{l}0.0252 * * * \\
(0.008)\end{array}$ & $\begin{array}{l}0.0303 * * * \\
(0.006)\end{array}$ \\
\hline Experience $\cdot t$ & $\begin{array}{c}0.0009 * \\
(0.0005)\end{array}$ & $\begin{array}{c}0.0022 \\
(0.0015)\end{array}$ & $\begin{array}{c}0.0026 \\
(0.003)\end{array}$ & $\begin{array}{c}0.0033 \\
(0.003)\end{array}$ & $\begin{array}{c}0.0016 \\
(0.002)\end{array}$ \\
\hline Experience $^{2}$ & $\begin{array}{c}-0.0005^{* * *} * \\
(0.0002)\end{array}$ & $\begin{array}{c}-0.0006^{* * * *} \\
(0.0001)\end{array}$ & $\begin{array}{c}-0.0009 * * * \\
(0.0001)\end{array}$ & $\begin{array}{c}-0.0006 * * * \\
(0.0002)\end{array}$ & $\begin{array}{c}-0.0007 * * * \\
(0.0001)\end{array}$ \\
\hline Experience $^{2} \cdot t$ & $\begin{array}{c}-0.00001 \\
(0.00002)\end{array}$ & $\begin{array}{c}-0.00005 \\
(0.00004)\end{array}$ & $\begin{array}{c}0.00006 \\
(0.00006)\end{array}$ & $\begin{array}{c}-0.00006 \\
(0.00007)\end{array}$ & $\begin{array}{c}-0.00002 \\
(0.00005)\end{array}$ \\
\hline
\end{tabular}

cantly over time. However, unlike those in table 8 (using cross-section data), the ownership-specific estimates in table 10 suggest that the return to experience is highest in the state, followed by the de novo and privatized firms. The difference between the cross-sectional and the longitudinal estimates based on starting wages is brought about almost entirely by a change in the coefficients of the state sector. Unlike in de novo and privatized firms, new jobs in the state sector have a steeper and more concave profile than existing (cross-sectional) state jobs. The profile of the new state jobs also peaks earlier (23 years) than that of existing jobs (26 years). We provide one insight into this phenomenon presently, but the asymmetry in compensating new versus existing workers in the state sector during the transition should be explored in more detail in future research.

An intriguing feature of our results is the finding that while state and privatized firms continue to rely on wage grids, the wage structures of these two sectors and of the de novo firms do not differ in a major way. This raises important questions of labor market dynamics during the transition, in particular whether de novo firms are replicating the structure of the wage grid or whether the wage grids follow the development of the private sector. In order to provide some insight into this issue, we have computed the average wage in ongoing jobs in 1989, starting wages in new jobs in the three sectors at the onset and at later points during the transition, and average wages in ongoing jobs in the three sectors in 1996. We find that at the start of the transition in the early 1990s, starting wages for new jobs in the state and privatized firms were virtually identical to the 1989 average wage in ongoing jobs. On the other hand, in the de novo firms the starting wage in the early 1990s (proxying also the average wage, because this was a new sector) was about
$40 \%$ higher. The starting wages in de novo firms did not grow much between 1992 and 1996, while they grew substantially in the state and privatized firms. ${ }^{37}$ By the end of 1996, the average wages for the ongoing jobs in the three sectors were very similar, with the state and privatized firms trailing the de novo firms by only about $10 \%$. Hence, de novo firms established themselves in the early transition labor market by paying considerably higher wages, but state and privatized firms gradually adjusted the parameters of their wage grids upward so that by 1996 they almost caught up with wages in the de novo firms. ${ }^{38}$ Our calculations in this area provide similar results to those obtained by Jurajda and Terrell (2002).

Our overall results for the transition period are similar to those of Flanagan (1998), but they differ from those of Chase (1998) and Krueger and Pischke (1995), who find a much flatter wage experience profile. ${ }^{39}$ Our estimates by ownership categories and an examination of the wage grid over time provide a possible explanation of this discrepancy. As may be seen from table 8 , the wage-experience profile is flatter in the state and privatized enterprises than in the de novo firms. Since Chase's (1998) and Krueger and Pischke's (1995) estimates relate to an earlier phase of the transition (1991 and 1993, respectively) when de novo firms were less prominent, the difference in the estimated wage experience

\footnotetext{
${ }^{37}$ The SOE wages stopped growing after 1994, whereas wages in privatized firms started growing later and continued until 1996.

${ }^{38}$ In the present calculations, we do not address the issue of heterogeneity in worker characteristics across the three sectors.

${ }^{39}$ Chase's (1998) coefficients on experience and experience squared are 0.014 and -0.0003 , respectively. The corresponding coefficients for Krueger and Pischke (1995) are 0.014 and -0.0002.
} 
profiles is likely to come from the different composition of firm ownership in these studies. ${ }^{40}$

\section{Returns to Communist Human Capital in the Transition}

Earlier studies have hypothesized that human capital acquired under communism is less appropriate for a market economy and it should hence receive a lower rate of return during the transition period than postcommunist human capital. Some labor economists and education specialists have also noted that apprenticeship and vocational education in the communist economies went well beyond what is observed in western market economies, and they expressed doubt about the value of that particular type of education in postcommunist labor markets. To test these hypotheses, we have identified for each man three measures of human capital: the number of years of education, the type of education, and the number of years of experience obtained under communism versus transition. We then test for differences in the returns to pre- and postcommunist human capital during the transition period.

In as much as $14 \%$ of the men in our 1996 sample concluded their education during 1990-1996, we have a sufficiently large sample to test three specifications. We begin by entering for each man as separate regressors his number of years of communist (old) education and his number of years of postcommunist (new) education. The estimated coefficients are 0.058 and 0.031 for old and new, respectively, and at the 5\% test level they are significantly different from 0 and from each other ${ }^{41}$ The finding that years of postcommunist education have a lower return than years of education obtained under communism strongly contradicts the first of the two hypotheses. We have checked whether the result arises because a large proportion of school leavers in 1990-1996 have lower levels of education (junior high school and apprentices) that we know command relatively low returns during transition, but we find that this is not the case. In a related test, we have estimated a model that allows the coefficient on years of education to be different for younger (than 30 years) and older men, proxying for two vintages of human capital that correlate with the communist and transition periods. The resulting estimates do not allow us to reject the hypothesis that the education of the younger and older men generates the same rate of return, thus again contradicting the first of the above two hypotheses. ${ }^{42}$ We have next tested for differences in returns to different levels of education (apprenticeships,

\footnotetext{
40 The various data sets may also have different age compositions of workers. In particular, depending on the number of workers that a sample contains from different age categories, one's estimates may reflect the concave or more flat parts of the wage-experience profile.

${ }^{41}$ The coefficient for communist education was $0.058($ s.e. $=0.005$ ), and the coefficient for postcommunist education was 0.031 (s.e. $=0.013$ ) $F(1,1610)=4.65$, with Prob $(>F)=0.03$.

42 The coefficients on the education coefficient for individuals younger than 30 and for those aged 30 or more are 0.063 and 0.059 , respectively,
}

vocational, academic high school, and university) obtained during versus after communism. We estimated our 1996 cross-sectional regression using as education regressors both levels of education and levels of education interacted with a dummy variable coded 1.0 for those who graduated after 1991. We find that whereas communist (pre-1992) education at all levels has positive returns, the interaction terms on postcommunist education have statistically significant negative coefficients for apprenticeships as well as vocational high school education (the interaction terms on postcommunist academic high school and university have insignificant effects). $F$-tests on whether for each level of education the sum of the communist (base) and postcommunist (interaction) coefficients exceeds 0 reject that hypothesis for apprenticeships but not other categories. These tests hence provide support for the second of the two aforementioned hypotheses, namely, that obtaining apprenticeship education during the transition does not add value relative to the base educational category of junior high school. They also indicate that the lower return to years of postcommunist than to communist education that we found above is driven by the lower returns to postcommunist apprenticeship and vocational high school education. Overall, our results contradict the hypothesis that education acquired under communism is less appropriate for a market economy than education obtained in transition. Rather, the findings are consistent with three other hypotheses: (i) education obtained under communism is (at least) as appropriate for a market economy as education obtained in transition, (ii) newly minted apprentices and vocational high school graduates command lower returns in the transition labor market than those who received this type of education earlier, and (iii) market-oriented (productivity- and earningsenhancing) reforms of the educational system have proceeded slowly during the transition. ${ }^{43}$

We have also tested the hypothesis that experience obtained after 1989 generates higher rates of return in the transition than experience accumulated under communism. This is a conjecture made by policymakers and several authors, including Krueger and Pischke (1995) and Flanagan (1998). However, the cross-sectional data used in previous studies did not permit a direct test of this hypothesis, because they do not have sufficient variation in the values of the postcommunist experience variable. We can carry out the test on the 1991-1996 job start data, and we find that individually and jointly the coefficients on the pre- and postcommunist experience and experience squared are not

in 1996. The $F$-test indicates that the hypothesis of zero difference cannot be rejected.

${ }^{43}$ The educational system went through a fundamental reform of financing and governance (see Filer \& Münich, 2000), and apprenticeship education in particular was in a state of chaos during the first phase of the transition. Under communism, apprenticeship centers were closely affiliated with specific SOEs that ensured the quality of the program and recruited the graduates. This symbiotic relationship disappeared during the privatization process, and the apprenticeship centers were transferred first to industrial ministries and later to the Ministry of Education. 
Figure 2.-SCATterplot of Estimated Coefficients ON INDUSTRY-SPeCIFIC Dummy VARIABLEs (1989 versus 1996)

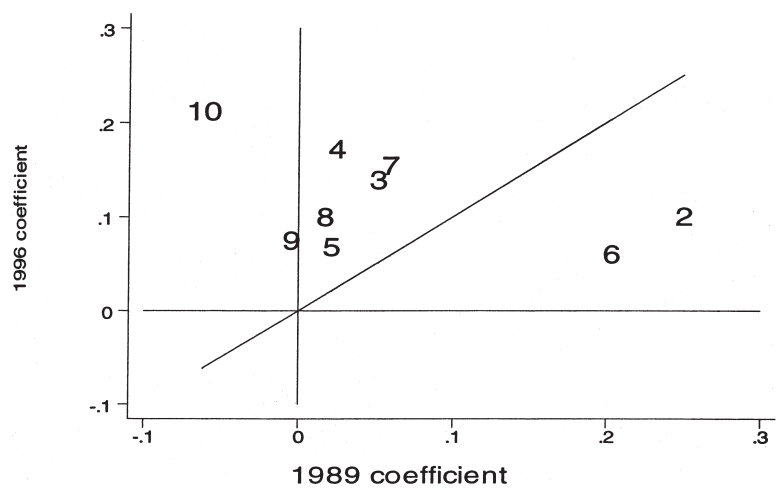

1 , agriculture $=$ base (excluded); 2 , mining, quarrying, and energy production and distribution; 3 , construction; 4 , wholesale, retail, and private services; 5 , public administration, education, health, and army; 6, Finance, insurance, and real estate; 7, Transportation and telecommunication; 8 , manufacturing-machinery; 9 , manufacturing-other; 10 , other.

different from one another. ${ }^{44}$ Our direct test hence suggests that communist and transition experience command the same rate of return during the transition.

\section{Shifts in Industry Wage Premiums between 1989 and 1996}

Students of the effects of communism on the labor markets have pointed out that the introduction of central planning altered the wage structure significantly from what it had been under the market system (e.g., Adam, 1984). In order to assess the extent to which the industry wage structure changed with the shift from central planning to the transition, we analyze industry intercepts from the 1989 and 1996 regressions in which we control for years of education and experience. These intercepts are industry wage differentials relative to agriculture, holding constant the composition of workers' human capital characteristics. ${ }^{45}$ As in the approach adopted by Krueger and Summers (1987), we plot the industry intercepts (coefficients) for 1989 against those for $1996 .{ }^{46}$ As seen in figure 2, major changes have taken place in the structure of intersectoral wage premiums. Rather than fitting along the positively sloped 45 degree line, the coefficients fit more closely to a downward-sloping line. ${ }^{47}$ Between 1989 and 1996, relative wages in finance and in mining and quarrying have decreased, while those in trade, transport and telecommunications, light manufacturing, and "other" activities gained. The long-term stability of the interindustry wage differentials in these countries, documented in the earlier literature, has therefore been disrupted by the transition.

\footnotetext{
44 The $F$-test value on the joint significance is $F(2,2078)=1.22$.

45 These coefficients are reported in full in table A3.

46 The reported pattern is very similar to the one obtained when one does not control for workers' human capital characteristics.

47 The nine-point scatter in fact generates a negative correlation coefficient of -0.41
}

In order to verify the scatter diagram analysis in figure 2, we report in table 11 the industry intercepts and tests for the significance of their 1989-versus-1996 differences. An examination of the intercept coefficients indicates that whereas under communism in 1989 only miners enjoyed a significant positive wage premium relative to those in agriculture, by 1996 seven of the nine sectors paid a premium. In analyzing pairwise 1989-1996 differences in the intercepts, we find that five are statistically significant. Men working in mining and quarrying indeed lost much of their former wage premium, with the decline occurring primarily in the privatized and de novo firms. Those in trade, transport, and telecommunications, light manufacturing, and "other" activities gained significantly, with most of the gain brought about by higher wage premia in the de novo firms, and in the case of transport and telecoms also the privatized firms. However, the seemingly large decline in finance, insurance, and real estate's wage differentials turns out not to be statistically significant. The interesting question is why we do not find a growing difference in intercepts in this expanding sector that has been hiring employees at very high wages. Our analysis indicates that the high wages of the employees in the finance sector reflect their relatively high levels of human capital and their concentrated location in the high-premium city of Prague. Finally, a more detailed analysis of the differentials in table 11 indicates that agriculture, the base sector, whose share in total output and employment shrank dramatically, lost also in terms of its wage differential relative to the rest of the economy. Overall, our findings suggest that the transition process is restoring some of the industry wage differentials that were attenuated or eliminated by central planning.

\section{Analysis of Unobserved Effects}

Unlike other studies, we observe the same individuals before and after the regime change and can provide a superior analysis of the variation of wages of individual workers over time. In particular, because managers had discretion in awarding wage premia under the communist wage grid, it is of interest to assess if individuals who had high or low wage premia (residuals) related to unobservable characteristics such as skills during communism also enjoyed these premia during the first 6 years of the transition. Using our regression estimates, we decompose the variance of worker-specific wages into the components due to observable determinants and those due to unobservable determinants in the old versus the new regime. This gives us an interesting insight into the persistence of unobserved components of workers' wages during the regime change.

\section{A. The Model}

Let observed logarithms of wages of individual $i$ under communism $(t=1)$ and during the transition $(t=2)$ be given by 
Table 11.-Changes in Industry Wage Structure from 1989 to $1996 \dagger$

\begin{tabular}{|c|c|c|c|c|c|c|}
\hline & \multirow{2}{*}{$\frac{\text { Communism (1989) }}{\text { All }}$} & \multicolumn{5}{|c|}{ Transition (1996) } \\
\hline & & All & Difference末 & State & Privatized & DeNovo \\
\hline Mining and quarrying & $\begin{array}{l}0.251 * * * \\
(0.039)\end{array}$ & $\begin{array}{l}0.092 * * \\
(0.044)\end{array}$ & $\begin{array}{l}-0.159 * * * \\
(0.007)\end{array}$ & $\begin{array}{l}0.245^{* *} \\
(0.099)\end{array}$ & $\begin{array}{c}0.063 \\
(0.058)\end{array}$ & $\begin{array}{r}-0.079 \\
(0.159)\end{array}$ \\
\hline Construction & $\begin{array}{l}0.051 \\
(0.035)\end{array}$ & $\begin{array}{l}0.131 * * * \\
(0.040)\end{array}$ & $\begin{array}{c}0.080 \\
(0.134)\end{array}$ & $\begin{array}{c}0.110 \\
(0.120)\end{array}$ & $\begin{array}{l}0.082 \\
(0.058)\end{array}$ & $\begin{array}{c}0.119 \\
(0.091)\end{array}$ \\
\hline $\begin{array}{l}\text { Wholesale and retail } \\
\text { trade }\end{array}$ & $\begin{array}{l}0.025 \\
(0.037)\end{array}$ & $\begin{array}{l}0.163^{* * * *} \\
(0.041)\end{array}$ & $\begin{array}{l}0.139 * * \\
(0.012)\end{array}$ & $\begin{array}{r}-0.134 \\
(0.138)\end{array}$ & $\begin{array}{l}0.060 \\
(0.062)\end{array}$ & $\begin{array}{l}0.147^{*} \\
(0.087)\end{array}$ \\
\hline $\begin{array}{l}\text { Public admin., education } \\
\text { and health }\end{array}$ & $\begin{array}{l}0.021 \\
(0.035)\end{array}$ & $\begin{array}{c}0.059 \\
(0.115)\end{array}$ & $\begin{array}{l}0.038 * * \\
(0.389)\end{array}$ & $\begin{array}{c}0.080 \\
(0.090)\end{array}$ & $\begin{array}{r}-0.190 \\
(0.219)\end{array}$ & $\begin{array}{c}0.0850 \\
(0.090)\end{array}$ \\
\hline $\begin{array}{l}\text { Finance, Ins., and real } \\
\text { estate }\end{array}$ & $\begin{array}{l}0.203 \\
(0.139)\end{array}$ & $\begin{array}{c}0.052 \\
(0.080)\end{array}$ & $\begin{array}{c}-0.152 \\
(0.345)\end{array}$ & $\begin{array}{l}0.140 \\
(0.171)\end{array}$ & $\begin{array}{c}0.054 \\
(0.116)\end{array}$ & $\begin{array}{c}-0.017 \\
(0.170)\end{array}$ \\
\hline $\begin{array}{l}\text { Transport and } \\
\text { telecommunications }\end{array}$ & $\begin{array}{c}0.059 \\
(0.036)\end{array}$ & $\begin{array}{l}0.146^{* * * *} \\
(0.040)\end{array}$ & $\begin{array}{l}0.087 * \\
(0.100)\end{array}$ & $\begin{array}{l}0.096 \\
(0.095)\end{array}$ & $\begin{array}{l}0.122^{*} \\
(0.062)\end{array}$ & $\begin{array}{l}0.275^{* * *} \\
(0.095)\end{array}$ \\
\hline $\begin{array}{l}\text { Manufacturing-food, } \\
\text { textile, }\end{array}$ & $\begin{array}{c}0.017 \\
(0.028)\end{array}$ & $\begin{array}{l}0.092 * * * \\
(0.033)\end{array}$ & $\begin{array}{l}0.075^{*} \\
(0.088)\end{array}$ & $\begin{array}{l}0.045 \\
(0.104)\end{array}$ & $\begin{array}{l}0.063 \\
(0.040)\end{array}$ & $\begin{array}{c}0.118 \\
(0.086)\end{array}$ \\
\hline $\begin{array}{l}\text { Manufacturing- } \\
\text { machinery }\end{array}$ & $\begin{array}{r}-0.005 \\
(0.030)\end{array}$ & $\begin{array}{c}0.066^{*} \\
(0.037)\end{array}$ & $\begin{array}{c}0.071 \\
(0.134)\end{array}$ & $\begin{array}{c}0.152 \\
(0.120)\end{array}$ & $\begin{array}{c}0.036 \\
(0.045)\end{array}$ & $\begin{array}{c}0.111 \\
(0.093)\end{array}$ \\
\hline Not known & $\begin{array}{r}-0.062 \\
(0.079)\end{array}$ & $\begin{array}{l}0.200 * * * \\
(0.038)\end{array}$ & $\begin{array}{l}0.262 * * * \\
(0.001)\end{array}$ & $\begin{array}{c}-0.133 \\
(0.137)\end{array}$ & $\begin{array}{c}-0.021 \\
(0.226)\end{array}$ & $\begin{array}{l}0.520 \text { *** } \\
(0.170)\end{array}$ \\
\hline
\end{tabular}

Note: Base $=$ agriculture

†Source: Table A3, education in years in all except the third column where $P$-values are reported.

$\neq$ Difference in 1989 and 1996 coefficients. $P$-values from chi-squared test on differences in coefficients are in parentheses.

\%, **, $* * *$ Statistically significant at the $10 \%, 5 \%, 1 \%$ level. Standard errors in parentheses.

$$
\begin{aligned}
& w_{1 i}=x_{1 i} \beta_{1}+\varepsilon_{1 i}, \\
& w_{2 i}=x_{2 i} \beta_{2}+\varepsilon_{2 i},
\end{aligned}
$$

where $x_{1 i}$ and $x_{2 i}$ are vectors of observed characteristics in each regime, the $\beta$ 's are vectors of corresponding coefficients, and the $\varepsilon$ 's reflect unobserved determinants of wages. The unobserved individual component of a person's wage in the first period, $\varepsilon_{1}$, may have an effect on the unobserved component in the second period, so that

$$
\varepsilon_{2 i}=\theta \varepsilon_{1 i}+v_{2 i} .
$$

The parameter $\theta$ captures the persistence of the unobserved individual-specific wage component across regimes, and $v_{2}$ captures the unobserved component of the wage that is introduced by the transition and is orthogonal to $\varepsilon_{1 i}$. Hence

$$
x_{1 i} \perp \varepsilon_{1 i}, \quad x_{2 i} \perp \varepsilon_{2 i}, \quad \text { and } \quad \varepsilon_{1 i} \perp v_{2 i} .
$$

Using equations (4) and (5), the relationship between variances in the unobserved wage can be expressed as

$$
\begin{gathered}
V\left(\varepsilon_{2 i}\right)=\theta^{2} V\left(\varepsilon_{1 i}\right)+V\left(v_{2 i}\right), \\
\operatorname{Cov}\left(\varepsilon_{1 i}, \varepsilon_{2 i}\right)=\theta V\left(\varepsilon_{1 i}\right) .
\end{gathered}
$$

Note that repeated cross-sectional data do not allow one to inspect the relationships in equation (6). Our panel data permit us to do so and also to analyze the variance of a worker-specific wage change, $V\left(w_{2 i}-w_{1 i}\right)$. Substituting from equation (4) into (3) and taking into account equation (6) yields

$$
\begin{aligned}
V\left(w_{2 i}-w_{1 i}\right)= & \left.V\left(x_{2 i} \beta_{2}+v_{2 i}+\theta \varepsilon_{1 i}-x_{1 i} \beta_{1}-\varepsilon_{1 i}\right)\right) \\
= & V\left[\left(x_{2 i} \beta_{2}-x_{1 i} \beta_{1}\right)\right. \\
& \left.+\varepsilon_{1 i}(\theta-1)+v_{2 i}\right] \\
= & V(\Delta B)+(\theta-1)^{2} V\left(\varepsilon_{1 i}\right)+V\left(v_{2 i}\right),
\end{aligned}
$$

where $\Delta B \equiv x_{2 i} \beta_{2}-x_{1 i} \beta_{1}$.

Equation (7) decomposes the variance of a workerspecific wage change into three mutually exclusive components: (i) the variance due to changes in observable worker and job characteristics and the coefficients of those characteristics, (ii) the variance due to workers' unobserved characteristics determining the wage in the first period, and (iii) the variance due to unobserved determinants of the wage that are introduced by the transition and are orthogonal to unobserved determinants in the first period.

The first component in equation (7) reflects changes in individual and job characteristics and the corresponding payoffs. For example, a rise in returns to education contributes positively to $V(\Delta B)$, whereas the effect of changing labor market experience depends on where the individual is on the concave wage-experience profile. The value of the second component depends on the persistence of the unobserved individual-specific effect. In the case of full persistence, $\theta=1$, the part played by unobserved characteristics in the unexplained variation of wages remains unchanged across the regimes, and regime change does not affect unobserved wage component of a worker's wage (e.g., general ability is rewarded equally under planning through the wage premium and in the wage setting during the 
transition). With no persistence, $\theta=0$, the unobserved component under communism does not translate into the unobserved component during the transition (e.g., entrepreneurial skills are rewarded only by the market and did not appear as an unobserved component in communist wages). One can also expect negative sorting, $\theta<0$, where Communist Party membership is for instance rewarded by a wage premium during communism, but is punished through negative wage discrimination during the transition. The value of the last term in equation (7) depends on the extent to which new unobserved components of wages, orthogonal to the unobserved wage component during communism, are introduced during the transition.

Applying the decomposition in equations (6) and (7) to our panel data, we are able to assess the extent to which wage changes experienced by individual workers stem from their observable characteristics versus unobservable timeinvariant and regime-specific effects.

\section{B. The Estimating Framework}

From the estimated coefficients $\hat{\beta}_{1}$ and $\hat{\beta}_{2}$, we calculate the residuals for each individual $i$ as

$$
\begin{aligned}
& \hat{\varepsilon}_{1 i}=w_{1 i}-x_{1 i} \hat{\beta}_{1}, \\
& \hat{\varepsilon}_{2 i}=w_{2 i}-x_{2 i} \hat{\beta}_{2} .
\end{aligned}
$$

The variances in equation (6) can be consistently estimated as

$$
\begin{aligned}
\hat{V}\left(\varepsilon_{t i}\right) & =V\left(\hat{\varepsilon}_{t i}\right)=\frac{1}{N} \sum_{i=1}^{N} \hat{\varepsilon}_{t i}^{2} \quad \text { for } t=1,2 \text { and } \\
i & =1, \ldots, N
\end{aligned}
$$

where $N$ is the number of individuals. The parameter $\theta$ can be obtained as an OLS coefficient in equation (4) or identically as

$$
\hat{\theta}=\operatorname{Cov}\left(\hat{\varepsilon}_{1 i}, \hat{\varepsilon}_{2 i}\right) / V\left(\hat{\varepsilon}_{1 i}\right) .
$$

The remaining variance in equation (7) is obtained by substituting estimates from equations (9) and (10) into (6):

$$
\hat{V}\left(v_{2 i}\right)=\hat{V}\left(\varepsilon_{2 i}\right)-\hat{\theta}^{2} \hat{V}\left(\varepsilon_{1 i}\right) .
$$

The variances in equation (7) contribute to the overall variance in wages as follows:

$$
\begin{aligned}
& V\left(w_{1 i}\right)=V\left(x_{1 i} \beta_{1}\right)+V\left(\varepsilon_{1 i}\right), \\
& V\left(w_{2 i}\right)=V\left(x_{2 i} \beta_{2}\right)+V\left(\varepsilon_{2 i}\right),
\end{aligned}
$$

and the variance in the deterministic components in equation (12) can be estimated as
Figure 3.-ScatterPlot of Residuals from Equation (8) Estimated WITH THE 1989 VERSUS 1996 DATA

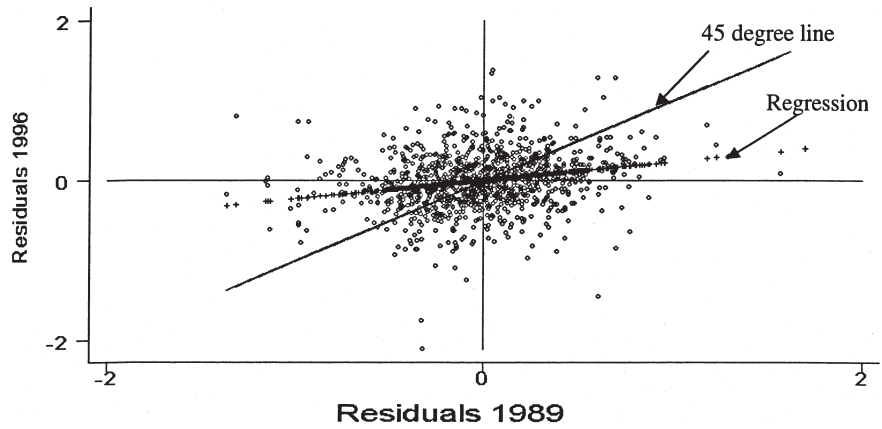

$$
\begin{aligned}
& \hat{V}\left(x_{1 i} \beta_{1}\right)=V\left(x_{1 i} \hat{\beta}_{1}\right), \\
& \hat{V}\left(x_{2 i} \beta_{2}\right)=V\left(x_{2 i} \hat{\beta}_{2}\right) .
\end{aligned}
$$

Finally,

$$
\hat{V}(\Delta B)=V(\Delta \hat{B}) .
$$

\section{Empirical Estimates}

As may be seen from figure 3 , there is a positive relationship in the scatterplot of the 1989 and 1996 residuals. The point estimate of the parameter $\theta$, capturing this relationship in terms of equation (4), is 0.23 with a standard error of 0.027 .

The estimates of the variance components of observed wages are presented in table 12 . The individual cells in the table correspond to the components in equations (6) and (7).

\begin{tabular}{|c|c|c|c|c|}
\hline & $V\left(w_{i}\right)$ & $V\left(X_{i} \beta\right)$ & $V\left(\varepsilon_{i}\right)$ & $V\left(v_{i}\right)$ \\
\hline \multicolumn{5}{|c|}{ A. Variance of Wages, $V\left(w_{i}\right)$} \\
\hline 1989 & 0.144 & 0.019 & 0.126 & - \\
\hline 1996 & 0.156 & 0.031 & 0.007 & 0.118 \\
\hline Within & 0.219 & 0.024 & 0.075 & 0.118 \\
\hline \multicolumn{5}{|c|}{ B. Variance in Percent of $V\left(w_{i}\right)$} \\
\hline 1989 & 100 & 13 & 88 & - \\
\hline 1996 & 100 & 20 & 4 & 76 \\
\hline Within & 100 & 11 & 34 & 54 \\
\hline \multicolumn{5}{|c|}{ C. Variance in Percent of $V\left(w_{i}\right)$ in 1989} \\
\hline 1989 & 100 & 13 & 88 & - \\
\hline 1996 & 108 & 22 & 5 & 82 \\
\hline Within & 152 & 17 & 52 & 82 \\
\hline
\end{tabular}
Rows 1989 and 1996 refer to cross-sectional variances in those years; the row titled "Within" refers to the variance in worker-specific wage changes. Panel A presents actual variances; panels $\mathrm{B}$ and $\mathrm{C}$ present variances as a percentage of the overall cross-sectional variance for each year and for 1989 , respectively. As may be seen throughout table 12, the variance in wages due to unobserved effects dominates the variance due to observable determinants. However, the variance due to observed determinants increases both abso-

TABle 12.-VARiance in Wages and Its Decomposition 
lutely (from 0.019 to 0.031 ) and in relative terms (from $13 \%$ to $20 \%$ of total variance) from communism in 1989 to the transition in 1996. The variation in wage changes experienced by individual workers is greater than the crosssectional variance in both regimes $(0.219>0.15$ in panel A), implying that individual workers experience substantial wage changes. Furthermore, panel B shows that $34 \%$ of the variance in wage changes experienced by individual workers is due to unobserved characteristics determining the wage already in 1989 (hence showing persistence over time), and $54 \%$ is due to new transition-specific unobserved determinants of wages that are orthogonal to those in 1989. Finally, $11 \%$ is due to changes in observed characteristics and their associated coefficients.

The fact that our decomposition estimates are by definition based on the sample of workers who worked in both periods raises the issue of whether our results are biased by excluding workers who worked in only one period. We recognize the problem, but think that this exclusion does not substantially change our results, for two reasons. First, between 1989 and 1996, labor force participation of Czech men was very high and the unemployment rate extremely low. Second, we have estimated the cross-sectional variances including all workers in each of the two years and found the results to be very similar to those presented in table 12 .

\section{Conclusions}

We estimate and test for changes in the returns to various kinds of human capital during the communist period and in transition to a market system. In sum, our study finds more changes in the returns to education than in the returns to experience. The transition brought about a major increase in the returns to a year of education, and the magnitude of this increase is similar in private de novo firms, privatized SOEs, and the state sector (SOEs and public administration). We find that those who have obtained (vocational) high school and university degrees experienced more rapid rates of increase in their returns than individuals with basic education (junior high school or apprentices). The sheepskin effect is prevalent and is especially detectable in transition and for higher levels of education in both regimes. Certain fields of study have experienced tremendous increases in their return (e.g., law), while others have not gained in the new market economy (e.g., health and education). On the other hand, with respect to experience, our estimates indicate that men's wage-experience profile was concave in both regimes and did not change from the communist to the transition period. However, we find that the de novo firms have a more concave and steeper profile than the state sector, indicating that de novo firms pay a higher return to new entrants than the state. Our results contradict the hypothesis that education acquired under communism is less appropriate for a market economy than education obtained in transition, and we in fact find that newly minted apprentices and vocational high school graduates command lower returns in the transition labor market than those who received this type of education earlier. Contrary to earlier conjectures, we also cannot reject the hypothesis that experience obtained under communism is rewarded identically to experience obtained during the transition.

Overall, our study provides two important insights into the functioning of the communist system and the transition economy. First, for decades the communist planners used the wage grid to maintain extremely low education-related wage differentials, but they also generated a significant amount of human capital that is as highly rewarded as postcommunist human capital in the nascent market economy. The communist system was hence able to maintain an effective educational system while decoupling it from education-related pecuniary rewards. Moreover, a large part of unobservable, individual-specific wage effects (e.g., skill premia) has carried over from communism to the market economy. Second, except for the greater concavity of the wage-experience profile in the de novo firms, firm ownership during the transition is found to be unrelated to wage differentials based on education and work experience. Hence, factors such as the reduction of state subsidies, the opening up of the economy to the world, and the possibility of competition in the labor market are sufficient to generate human-capital-related wage differentials that on average do not vary with principal types of firm ownership in the economy. The data indicate that the de novo firms established themselves in the early transition by paying considerably higher wages, but state and privatized firms gradually adjusted their wage grids upward so that by 1996 they almost caught up with wages in the de novo firms.

\section{REFERENCES}

Adam, Jan, Employment and Wage Policies in Poland, Czechoslovakia, and Hungary since 1950 (New York: St. Martin's Press, 1984).

Atkinson, A. B., and J. Micklewright, Economic Transformation in Eastern Europe and the Distribution of Income (Cambridge, U.K.: Cambridge University Press, 1992).

Basu, S., S. Estrin, and J. Svejnar, "Employment and Wage Behavior of Enterprises in Transitional Economies," The William Davidson Institute, University of Michigan Business School, working paper no.114 (1999).

Bird, E. J., J. Schwarze, and G. G. Wagner, "Wage Effects of the Move towards Free Markets in East Germany," Industrial and Labor Relations Review 47:3 (1994), 390-400.

Card, D., and A. B. Krueger, "Does School Quality Matter? Returns to Education and the Characteristics of Public Schools in the United States," Journal of Political Economy 100 (February 1992), 1-40.

Chase, R. S., "Markets for Communist Human Capital: Returns to Education and Experience in Post-Communist Czech Republic and Slovakia," Industrial and Labor Relations Review 51:3 (1998), 401-423.

Dyba, K., and J. Svejnar, "A Comparative View of Economic Developments in the Czech Republic," in J. Svejnar (Ed.), The Czech Republic and Economic Transition in Eastern Europe (San Diego: Academic Press, 1995).

Filer, R., and D. Münich, "Responses of Private and Public Schools to Voucher Funding: The Czech and Hungarian Experience," CERGEEI working paper no. 160 (2000). 
Flanagan, R. J., "Wage Structure in the Transition of the Czech Economy," IMF working paper no. 95/36 (1996).

"Were Communists Good Human Capitalists? The Case of the Czech Republic," Labour Economics 5 (1998), 295-312.

Heckman, J., "Sample Selection Bias as a Specification Error," Econometrica 47:1 (1979), 153-161.

Heckman, J., A. Layne-Farrar, and P. Todd, Does Measured School Quality Really Matter? An Examination of Earnings-Quality Relationship (Brookings Institution Press, 1996).

Hungerford, T., and G. Solon, "Sheepskin Effects in the Returns to Education," this REVIEW, 69 (February 1987), 175-177.

Jaeger, D. A., and M. E. Page, "Degrees Matter: New Evidence on Sheepskin Effects in the Returns to Education," this REVIEW, 78:4 (1996), 733-740.

Jones, D. C., and K. Ilayperuma, "Wage Determination under Plan and Early Transition: Evidence from Bulgaria," Department of Economics, Hamilton College, working paper no. 94/5 (1994).

Jurajda, S., and K. Terrell, "What Drives the Speed of Transition during Episodes of Massive Reallocation?" William Davidson Institute working paper no. 432 (2002).

Krueger, A. B., and J.-S. Pischke, "A Comparative Analysis of East and West German Labor Markets: Before and After Unification," in R. B. Freeman, and F. Katz (Eds.), Differences and Changes in Wage Structures (Chicago: The University of Chicago Press, 1995).

Krueger, A. B., and L. H. Summers, "Reflections on the Inter-industry Wage Structure," in Kevin Lang and Jonathan Leonard (Eds.), Unemployment and the Structure of Labour Markets (Oxford: Basil Blackwell, 1987).

Layard, R., and G. Psacharopoulos, "The Screening Hypothesis and the Returns to Education," Journal of Political Economy 82 (1974), 985-998.

Mincer, J., and H. Ofek, "Interrupted Work Careers: Depreciation and Restoration of Human Capital," Journal of Human Resources 17 (1982), 3-24.

Mincer, J., and S. Polachek, "Family Investment in Human Capital: Earnings of Women," Journal of Political Economy 82 (1974), S76-S108.

Ministry of Agriculture of the Czechoslovak Republic, Wage Adjustments and Premia for Pig Tenders on State Farms [Mzdové úpravy a prémie pro ošetrovatele prasat na státních statcích] (Prague: Brázda, 1952).

Ministry of Labor and Social Affairs of the Czechoslovak Federal Republic, News of the Federal Ministry of Labor and Social Affairs [Zpravodaj federálního ministerstva sociálních věcí] 1: 1 (November 1985).

News of the Federal Ministry of Labor and Social Affairs [Zpravodaj federálního ministerstva sociálních věcí] 1:2-3 (January 1986).

Münich, D., J. Svejnar, and K. Terrell, "Final Report to the Czech Ministry of Labor and Social Affairs on the Retrospective Questionnaire on Employment Histories," unpublished (1997).

"Do Markets Favor Women's Human Capital More than Planners Did?" Journal of Comparative Economics, forthcoming, 2005.

Nesterova, D., and K. Sabirianova, "Investment in Human Capital during the Economic Transformation in Russia," Economic Education Research Consortium working paper, Moscow (1999).

Orazem, P. F., and M. Vodopivec, "Unemployment in Eastern Europe, Value of Human Capital in Transition to Market: Evidence from Slovenia," European Economic Review 41 (1997), 893-903.

Paukert, L., "Economic Transition and Women's Employment in Four Central European Countries, 1989-1994," Labor Market Papers no. 7, International Labor Office, Geneva (1995).

Rutkowski, J., "Wage Determination in Late Socialism: The case of Poland," Economics of Planning 27 (1994), 135-164.

"High Skills Pay-off: The Changing Wage Structure during Economic Transition in Poland," Economics of Transition 4:1 (1996), $89-112$.

Svejnar, J., "Czechoslovak Labor Relations: The Postwar Experience: Part I," Industrial and Labor Relations Forum X:1 (1974a), 35-52. "Czechoslovak Labor Relations: The Postwar Experience: Part II," Industrial and Labor Relations Forum X:2 (1974b), 121-146.
White, H., "A Heteroskedascity-Consistent Covariance Matrix Estimator and a Direct Test for the Heteroskedasticity," Econometrica 48 (1980), 817-830.

Windmuller, J., "Czechoslovakia and the Communist Union Model," British Journal of Industrial Relations 9:1 (1970), 1-37.

\section{APPENDIX}

Table A1.-Means and Standard Deviation of Variables in CRoss-Sectional Data

\begin{tabular}{|c|c|c|c|c|}
\hline & \multicolumn{2}{|c|}{1989} & \multicolumn{2}{|c|}{1996} \\
\hline & Mean & St. Dev. & Mean & St. Dev. \\
\hline Log of monthly wage & 8.227 & $(0.394)$ & 8.961 & (0.404) \\
\hline Experience (years) & 18.2 & (11.458) & 20.4 & (11.992) \\
\hline Experience $^{2}$ & 463.3 & $(490.445)$ & 559.8 & $(545.452)$ \\
\hline Education in years & 12.776 & (2.519) & 12.626 & $(2.347)$ \\
\hline
\end{tabular}

in years education:

Junior high school (reference group)

Apprentices with 2 years

Apprentices with 3 years

Vocational HS with 4 years

Academic HS with 4 years

University

Field of highest level of education:

Apprenticeship:

Machine control

Manuf. machinery and metallurgy

Elect. eng., transport, telecomm.

Chemistry, food processing

Textile, clothing

Wood, shoe manufacturing

Construction

Agriculture, forestry

Trade, services

Other

Academic high school

Vocational high school:

Natural sciences

Manufacturing-machinery

Electrical engineering

Construction

Other technical branches

Agriculture

Health

Business, trade, services

Law

Teaching

Other social branches

Other

University:

Natural sciences

Manufacturing-Machinery

Electrical engineering

Construction

Other technical

branches

Agriculture

Health

Business, trade, services

Law

Teaching

Other social branches

Other

\begin{tabular}{|c|c|c|c|}
\hline 0.057 & $(0.394)$ & 0.047 & $(0.212)$ \\
\hline 0.048 & $(0.213)$ & 0.035 & $(0.184)$ \\
\hline 0.484 & $(0.500)$ & 0.503 & $(0.500)$ \\
\hline 0.258 & $(0.438)$ & 0.274 & $(0.446)$ \\
\hline 0.022 & $(0.147)$ & 0.023 & (0.149) \\
\hline 0.131 & $(0.338)$ & 0.119 & $(0.323)$ \\
\hline 0.028 & $(0.164)$ & 0.029 & $(0.168)$ \\
\hline 0.199 & (0.399) & 0.200 & $(0.400)$ \\
\hline 0.069 & $(0.254)$ & 0.073 & $(0.260)$ \\
\hline 0.016 & $(0.125)$ & 0.018 & $(0.132)$ \\
\hline 0.007 & $(0.084)$ & 0.004 & $(0.061)$ \\
\hline 0.025 & $(0.157)$ & 0.031 & $(0.173)$ \\
\hline 0.089 & $(0.284)$ & 0.089 & $(0.284)$ \\
\hline 0.040 & (0.197) & 0.042 & $(0.202)$ \\
\hline 0.029 & $(0.168)$ & 0.022 & $(0.145)$ \\
\hline 0.030 & $(0.170)$ & 0.031 & $(0.173)$ \\
\hline 0.022 & $(0.147)$ & 0.023 & $(0.149)$ \\
\hline 0.004 & $(0.060)$ & 0.002 & $(0.050)$ \\
\hline 0.091 & $(0.288)$ & 0.094 & $(0.292)$ \\
\hline 0.046 & $(0.209)$ & 0.058 & $(0.235)$ \\
\hline 0.019 & (0.136) & 0.017 & $(0.130)$ \\
\hline 0.016 & $(0.127)$ & 0.018 & $(0.135)$ \\
\hline 0.023 & $(0.149)$ & 0.022 & (0.147) \\
\hline 0.003 & $(0.055)$ & 0.006 & $(0.074)$ \\
\hline 0.028 & $(0.164)$ & 0.027 & $(0.162)$ \\
\hline 0.001 & $(0.032)$ & 0.001 & $(0.035)$ \\
\hline 0.002 & $(0.045)$ & 0.002 & $(0.050)$ \\
\hline 0.005 & $(0.071)$ & 0.004 & $(0.065)$ \\
\hline 0.021 & $(0.142)$ & 0.020 & $(0.141)$ \\
\hline 0.010 & $(0.098)$ & 0.007 & $(0.082)$ \\
\hline 0.023 & $(0.150)$ & 0.024 & $(0.153)$ \\
\hline 0.009 & $(0.096)$ & 0.009 & $(0.096)$ \\
\hline 0.013 & $(0.112)$ & 0.012 & $(0.107)$ \\
\hline 0.010 & (0.101) & 0.008 & $(0.089)$ \\
\hline 0.013 & $(0.115)$ & 0.012 & (0.107) \\
\hline 0.008 & $(0.087)$ & 0.008 & (0.089) \\
\hline 0.012 & $(0.110)$ & 0.009 & $(0.096)$ \\
\hline 0.006 & $(0.078)$ & 0.005 & $(0.070)$ \\
\hline 0.016 & $(0.125)$ & 0.015 & (0.123) \\
\hline 0.005 & $(0.068)$ & 0.004 & $(0.061)$ \\
\hline 0.006 & $(0.078)$ & 0.006 & (0.078) \\
\hline
\end{tabular}

212)

$0.500)$

.149)

168)

132)

.061)

284

202)

$(0.145)$

$0.149)$

.050)

$(0.292)$

.130)

135)

(0.162)

$0.050)$

.065)

$0.141)$

$0.096)$

.107)

.089)

$0.096)$

$0.061)$ 
TABLE A1.-(CONTINUED)

\begin{tabular}{|c|c|c|c|c|}
\hline & \multicolumn{2}{|c|}{1989} & \multicolumn{2}{|c|}{1996} \\
\hline & Mean & St. Dev. & Mean & St. Dev. \\
\hline \multicolumn{5}{|l|}{ Other variables: } \\
\hline Prague & 0.106 & $(0.307)$ & 0.116 & $(0.320)$ \\
\hline Child benefits included & 0.197 & $(0.398)$ & 0.110 & $(0.313)$ \\
\hline Gross earnings reported & 0.247 & $(0.431)$ & 0.226 & $(0.418)$ \\
\hline \multicolumn{5}{|l|}{ Industry: } \\
\hline Mining and quarrying & 0.088 & $(0.283)$ & 0.074 & $(0.261)$ \\
\hline Construction & 0.116 & $(0.320)$ & 0.122 & $(0.327)$ \\
\hline Wholesale retail & 0.099 & $(0.299)$ & 0.138 & $(0.345)$ \\
\hline Broad public & 0.127 & $(0.333)$ & 0.136 & $(0.343)$ \\
\hline \multicolumn{3}{|l|}{ Finance, insurance, } & 0.015 & $(0.121)$ \\
\hline $\begin{array}{l}\text { Transport, } \\
\text { telecommunications }\end{array}$ & 0.082 & $(0.274)$ & 0.082 & $(0.274)$ \\
\hline $\begin{array}{l}\text { Manufacturing-food, } \\
\text { textile }\end{array}$ & 0.241 & $(0.428)$ & 0.252 & $(0.434)$ \\
\hline Manufacturing-machinery & 0.118 & $(0.323)$ & 0.112 & $(0.315)$ \\
\hline $\begin{array}{l}\text { Households }+ \text { exterritorial } \\
+ \text { not known }\end{array}$ & 0.010 & $(0.101)$ & 0.009 & $(0.096)$ \\
\hline \multicolumn{5}{|l|}{ Firm sizes } \\
\hline 1-25 employees & & & 0.258 & $(0.438)$ \\
\hline 26-100 employees & & & 0.211 & $(0.408)$ \\
\hline 101-500 employees & & & 0.238 & $(0.426)$ \\
\hline$>500$ employees & & & 0.256 & $(0.437)$ \\
\hline Not known & & & 0.037 & $(0.214)$ \\
\hline \multicolumn{5}{|l|}{ Ownership: } \\
\hline Privatized & & & 0.310 & $(0.445)$ \\
\hline \multicolumn{5}{|l|}{ SOE \& public } \\
\hline administration & & & 0.236 & $(0.341)$ \\
\hline De novo private & & & 0.371 & $(0.483)$ \\
\hline Other \& not known & & & 0.083 & $(0.276)$ \\
\hline \multicolumn{5}{|l|}{ Employment status: } \\
\hline Employee & & & 0.900 & \\
\hline Employer & & & 0.025 & $(0.157)$ \\
\hline Self-employed & & & 0.067 & $(0.250)$ \\
\hline HH helper + not known & & & 0.008 & $(0.089)$ \\
\hline \multicolumn{4}{|l|}{ Log of district-level } & $(0.021)$ \\
\hline No. of obs. & & 51 & & 27 \\
\hline
\end{tabular}

Table A2.-Means and Standard Deviations of Variables FOR START DATE DATA

\begin{tabular}{|c|c|c|c|c|}
\hline & \multicolumn{2}{|c|}{ Communism } & \multicolumn{2}{|c|}{ Transition } \\
\hline & Mean & St. Dev. & Mean & St. Dev. \\
\hline Log of earnings & 8.049 & $(0.549)$ & 8.509 & $(0.484)$ \\
\hline Experience & 7.009 & (9.178) & 13.442 & $(12.653)$ \\
\hline Exper. $\times$ time & -640 & $(1184.843)$ & 381 & $(534.646)$ \\
\hline Experience $^{2}$ & 135 & $(302.504)$ & 341 & $(511.855)$ \\
\hline Exper. $^{2}$ time & -921 & $(2053.821)$ & 786 & $(1598.660)$ \\
\hline Years of education & 12.843 & $(2.526)$ & 12.428 & (2.261) \\
\hline Education $\times$ time & -151 & (126.817) & 32 & (23.523) \\
\hline Apprentice (2 years) & 0.037 & $(0.190)$ & 0.036 & $(0.185)$ \\
\hline Apprentice $(2) \times$ time & & & 0.088 & $(0.572)$ \\
\hline Apprentice (3 years) & 0.475 & $(0.500)$ & 0.533 & (0.499) \\
\hline Apprentice $(3) \times$ time & -5.4 & $(8.482)$ & 1.4 & $(1.836)$ \\
\hline Vocational HS & 0.268 & $(0.443)$ & 0.243 & $(0.429)$ \\
\hline Vocational HS $\times$ time & -3.3 & $(7.300)$ & 0.6 & (1.442) \\
\hline Academic HS & 0.022 & $(0.146)$ & 0.036 & $(0.185)$ \\
\hline Academic HS $\times$ time & -0.3 & $(2.501)$ & 0.1 & $(0.671)$ \\
\hline University & 0.143 & $(0.350)$ & 0.101 & $(0.302)$ \\
\hline University $\times$ time & -1.4 & $(5.016)$ & 0.2 & $(0.896)$ \\
\hline Prague & 0.111 & $(0.314)$ & 0.121 & $(0.327)$ \\
\hline Child ben. incl. & 0.136 & $(0.343)$ & 0.089 & $(0.284)$ \\
\hline Gross earnings & 0.258 & $(0.437)$ & 0.226 & $(0.418)$ \\
\hline Machine control & 0.093 & $(0.290)$ & 0.049 & $(0.216)$ \\
\hline Elect. eng., trans., telecomm. & 0.098 & $(0.298)$ & 0.175 & $(0.380)$ \\
\hline Chemistry, food processing & 0.096 & $(0.295)$ & 0.187 & $(0.390)$ \\
\hline Textiles, clothing & 0.125 & $(0.331)$ & 0.112 & $(0.315)$ \\
\hline Wood, shoe manuf. & 0.007 & $(0.083)$ & 0.012 & $(0.108)$ \\
\hline Construction & 0.075 & $(0.264)$ & 0.062 & $(0.241)$ \\
\hline Agriculture, forestry & 0.244 & $(0.429)$ & 0.254 & $(0.435)$ \\
\hline Trade, services & 0.134 & $(0.341)$ & 0.080 & $(0.272)$ \\
\hline Other & 0.007 & $(0.083)$ & 0.008 & $(0.089)$ \\
\hline 1-25 employees & & & 0.336 & $(0.472)$ \\
\hline 26-100 employees & & & 0.245 & $(0.430)$ \\
\hline 101-500 employees & & & 0.209 & $(0.407)$ \\
\hline$>500$ employees & & & 0.172 & $(0.377)$ \\
\hline Not known & & & 0.038 & $(0.192)$ \\
\hline Privatized & & & 0.196 & $(0.397)$ \\
\hline SOE \& public admin. & & & 0.229 & $(0.420)$ \\
\hline De novo private & & & 0.495 & $(0.500)$ \\
\hline Other \& not known & & & 0.081 & $(0.272)$ \\
\hline Employee & & & 0.911 & \\
\hline Employer & & & 0.018 & $(0.131)$ \\
\hline Self-employed & & & 0.061 & $(0.240)$ \\
\hline $\mathrm{HH}$ helper + not known & & & 0.010 & $(0.102)$ \\
\hline No. of obs. & \multicolumn{2}{|c|}{1285} & \multicolumn{2}{|c|}{2107} \\
\hline
\end{tabular}

Table A3.-Cross-Sectional Earnings Functions, 1989 And 1996 (EduCATion by Years)

\begin{tabular}{|c|c|c|c|c|c|c|c|}
\hline & \multicolumn{2}{|c|}{ Communism } & \multicolumn{5}{|c|}{ Transition } \\
\hline & All (1) & All (2) & All (1) & All (2) & State & Privatized & DeNovo \\
\hline Education & $0.026(0.003)$ & $0.027(0.005)$ & $0.058(0.004)$ & $0.058(0.005)$ & $0.056(0.009)$ & $0.065(0.007)$ & $0.061(0.010)$ \\
\hline Experience & $0.022(0.003)$ & $0.021(0.003)$ & $0.020(0.005)$ & $0.021(0.005)$ & $0.015(0.006)$ & $0.022(0.007)$ & $0.030(0.004)$ \\
\hline Experience $^{2}$ & $-0.0005(0.0001)$ & $-0.0004(0.0001)$ & $-0.0004(0.0001)$ & $-0.0004(0.0001)$ & $0.000(0.000)$ & $0.000(0.000)$ & $-0.00(0.000)$ \\
\hline Prague & - & $0.015(0.027)$ & - & $0.120(0.032)$ & $0.151(0.047)$ & $0.088(0.064)$ & $0.17(0.057)$ \\
\hline Child benefits included & - & $0.061(0.022)$ & - & $0.064(0.026)$ & $0.051(0.042)$ & $0.112(0.052)$ & $0.054(0.045)$ \\
\hline Gross earinings & - & $0.122(0.020)$ & - & $0.069(0.022)$ & $0.082(0.041)$ & $0.045(0.031)$ & $0.09(0.040)$ \\
\hline \multicolumn{8}{|l|}{ Industry: } \\
\hline Mining and quarrying & - & $0.251(0.039)$ & - & $0.092(0.044)$ & $0.245(0.099)$ & $0.063(0.058)$ & $-0.07(0.159)$ \\
\hline Construction & - & $0.051(0.035)$ & - & $0.131(0.040)$ & $0.110(0.120)$ & $0.082(0.058)$ & $0.11(0.091)$ \\
\hline Wholesale and retail Trade & - & $0.025(0.037)$ & - & $0.163(0.041)$ & $-0.134(0.138)$ & $0.060(0.062)$ & $0.14(0.087)$ \\
\hline $\begin{array}{l}\text { Public admin., education, } \\
\text { and Health }\end{array}$ & - & $0.021(0.035)$ & & & ) & $-0190(0219)$ & \\
\hline Finance, ins., and real estate & - & $\begin{array}{l}0.021(0.035) \\
0.203(0.139)\end{array}$ & - & $\begin{array}{l}0.059(0.115) \\
0.052(0.080)\end{array}$ & $0.080(0.090)$ & $\begin{array}{r}-0.190(0.219) \\
0.054(0.116)\end{array}$ & $\begin{array}{r}0.08(0.090) \\
-0.01(0.170)\end{array}$ \\
\hline Transport and & & $0.205(0.159)$ & - & $0.052(0.000)$ & $0.140(0.1 / 1)$ & $0.054(0.116)$ & $-0.01(0.1 / 0)$ \\
\hline Telecommunications & - & $0.059(0.036)$ & - & $0.146(0.040)$ & $0.096(0.095)$ & $0.122(0.062)$ & $0.27(0.095)$ \\
\hline $\begin{array}{l}\text { Manufacturing-food, } \\
\text { textile }\end{array}$ & & (017 & & & & & \\
\hline $\begin{array}{l}\text { text1le } \\
\text { Manufacturing- }\end{array}$ & - & $0.017(0.028)$ & - & $0.092(0.033)$ & $0.045(0.104)$ & $0.063(0.040)$ & $0.11(0.086)$ \\
\hline machinery & - & $-0.005(0.030)$ & - & $0.066(0.037)$ & $0.152(0.120)$ & $0.036(0.045)$ & $0.11(0.093)$ \\
\hline Not known & - & $-0.062(0.079)$ & - & $0.200(0.038)$ & $-0.133(0.137)$ & $-0.021(0.226)$ & $0.52(0.170)$ \\
\hline Constant & $7.704(0.050)$ & $7.620(0.055)$ & $8.060(0.063)$ & $7.916(0.071)$ & $7.919(0.143)$ & $7.812(0.099)$ & $7.84(0.157)$ \\
\hline Adj. $R^{2}$ & 0.069 & 0.118 & 0.162 & 0.190 & 0.256 & 0.23 & 0.23 \\
\hline No. of obs. & 1955 & 1951 & 1639 & 1627 & 384 & 504 & 604 \\
\hline
\end{tabular}

Base $=$ people working outside Prague, whose earnings are net of tax and child benefits, and who work in agriculture. Standard error in parentheses 
Table A4.-Cross-Sectional Earnings Functions, 1989 And 1996 (EduCATion by Levels)

\begin{tabular}{|c|c|c|c|c|c|c|c|}
\hline & \multicolumn{2}{|c|}{ Communism } & \multicolumn{5}{|c|}{ Transition } \\
\hline & (1) & (2) & (1) & (2) & State & Privatized & DeNovo \\
\hline Apprentice ( 2 years) & $0.0701(0.052)$ & $0.0635(0.051)$ & $0.1128(0.058)$ & $0.0939(0.057)$ & $0.1290(0.121)$ & $0.1143(0.065)$ & $0.100(0.137)$ \\
\hline Apprentice (3 years) & $0.0923(0.038)$ & $0.0773(0.037)$ & $0.1434(0.049)$ & $0.1122(0.049)$ & $0.0968(0.105)$ & $0.1559(0.058)$ & $0.065(0.115)$ \\
\hline Vocational HS & $0.1374(0.040)$ & $0.1265(0.040)$ & $0.3228(0.050)$ & $0.2943(0.050)$ & $0.3232(0.105)$ & $0.3266(0.058)$ & $0.249(0.118)$ \\
\hline Academic HS & $0.1525(0.080)$ & $0.1346(0.081)$ & $0.3822(0.102)$ & $0.3508(0.107)$ & $0.4011(0.142)$ & $0.2656(0.164)$ & $0.342(0.309)$ \\
\hline University & $0.2793(0.044)$ & $0.2826(0.045)$ & $0.5515(0.058)$ & $0.5439(0.059)$ & $0.4758(0.115)$ & $0.6734(0.072)$ & $0.599(0.133)$ \\
\hline Experience & $0.0220(0.003)$ & $0.0210(0.003)$ & $0.0240(0.005)$ & $0.0240(0.005)$ & $0.0210(0.006)$ & $0.0270(0.007)$ & $0.0300(0.004)$ \\
\hline Experience $^{2}$ & $-0.0005(0.0001)$ & $-0.0005(0.0001)$ & $-0.0005(0.0001)$ & $-0.0005(0.0001)$ & $-0.0004(0.0001)$ & $-0.0005(0.0002)$ & $-0.0008(0.0001)$ \\
\hline Prague & - & $0.009(0.027)$ & - & $0.102(0.032)$ & $0.142(0.047)$ & $0.045(0.061)$ & $0.140(0.055)$ \\
\hline Child benefits included & - & $0.065(0.021)$ & - & $0.076(0.026)$ & $0.056(0.042)$ & $0.122(0.051)$ & $0.07(0.044)$ \\
\hline \multirow{2}{*}{\multicolumn{8}{|c|}{ Sector: }} \\
\hline & & & & & & & \\
\hline Mining and quarrying & - & $0.250(0.039)$ & - & $0.095(0.043)$ & $0.271(0.089)$ & $0.063(0.058)$ & $-0.04(0.150)$ \\
\hline Construction & - & $0.053(0.035)$ & - & $0.145(0.040)$ & $0.150(0.114)$ & $0.096(0.060)$ & $0.14(0.091)$ \\
\hline Wholesale and retail trade & - & $0.020(0.036)$ & - & $0.150(0.040)$ & $-0.067(0.120)$ & $0.028(0.058)$ & $0.13(0.086)$ \\
\hline $\begin{array}{l}\text { Public admin., education, } \\
\text { and health }\end{array}$ & - & $0.012(0.035)$ & - & $0.034(0.038)$ & $0.095(0.080)$ & $-0.039(0.210)$ & $0.06(0.102)$ \\
\hline Finance, ins. \& real estate & - & $0.210(0.131)$ & - & $0.024(0.076)$ & $0.091(0.157)$ & $0.046(0.119)$ & $-0.06(0.185)$ \\
\hline Transport and & & & & & & & \\
\hline telecommunications & - & $0.057(0.036)$ & - & $0.149(0.039)$ & $0.115(0.087)$ & $0.144(0.057)$ & $0.30(0.094)$ \\
\hline $\begin{array}{l}\text { Manufacturing-food, } \\
\text { textile }\end{array}$ & - & $0.018(0.028)$ & - & $0.092(0.032)$ & $0.077(0.097)$ & $0.063(0.039)$ & $0.13(0.085)$ \\
\hline Manufacturing- & & & & & & & \\
\hline machinery & - & $-0.010(0.030)$ & - & $0.066(0.036)$ & $0.172(0.116)$ & $0.026(0.044)$ & $0.13(0.091)$ \\
\hline Not known & - & $-0.064(0.082)$ & - & $0.180(0.111)$ & $-0.167(0.094)$ & $-0.016(0.223)$ & $0.52(0.176)$ \\
\hline Constant & $7.910(0.043)$ & $7.847(0.046)$ & $8.516(0.054)$ & $8.404(0.059)$ & $8.331(0.136)$ & $8.324(0.077)$ & $8.40(0.143)$ \\
\hline$R^{2}$ & 0.070 & 0.120 & 0.181 & 0.210 & 0.280 & 0.270 & 0.270 \\
\hline No. of obs. & 1955 & 1951 & 1639 & 1627 & 384 & 504 & 604 \\
\hline
\end{tabular}

Base $=$ junior high school graduates working outside Prague in agriculture, whose earnings are net of tax and child benefits. Standard errors in parentheses.

TAble A5.-Cross-Sectional EARnings Functions, 1989 And 1996 (EduCAtion by Levels AND Field of Study)

\begin{tabular}{|c|c|c|c|c|c|}
\hline & 1989 & 1996 & & 1989 & 1996 \\
\hline $\begin{array}{l}\text { Apprenticeship fields of } \\
\text { study: }\end{array}$ & & & $\begin{array}{l}\text { Fields within university } \\
\text { education: (cont'd) }\end{array}$ & & \\
\hline Machine control & $0.123(0.053)$ & $0.084(0.062)$ & Other technical branches & $0.488(0.079)$ & $0.753(0.136)$ \\
\hline Manuf. machinery and & & & Agriculture & $0.305(0.077)$ & $0.496(0.080)$ \\
\hline metallurgy & $0.113(0.040)$ & $0.139(0.051)$ & Health & $0.315(0.091)$ & $0.246(0.166)$ \\
\hline Elec. eng., transport, & & & Business, trade, services & $0.350(0.117)$ & $0.643(0.144)$ \\
\hline telecomm. & $0.076(0.045)$ & $0.122(0.056)$ & Law & $0.394(0.112)$ & $1.054(0.138)$ \\
\hline Chemistry, food processing & $0.122(0.068)$ & $0.031(0.085)$ & Teaching & $0.266(0.083)$ & $0.314(0.091)$ \\
\hline Textile, clothing & $-0.056(0.071)$ & $-0.194(0.133)$ & Other social branches & $0.129(0.087)$ & $0.139(0.101)$ \\
\hline Wood, shoe manufacturing & $0.071(0.056)$ & $0.073(0.061)$ & Other & $-0.007(0.129)$ & $0.548(0.088)$ \\
\hline Construction & $0.054(0.046)$ & $0.154(0.060)$ & Experience & $0.021(0.003)$ & $0.025(0.0049)$ \\
\hline Agriculture, forestry & $-0.040(0.053)$ & $-0.007(0.064)$ & Experience $^{2}$ & $-(0.00044)(0.00006)$ & $-(0.00052)(0.0001)$ \\
\hline Trade, services & $0.007(0.067)$ & $0.161(0.071)$ & Prague & $0.008(0.028)$ & $0.108(0.031)$ \\
\hline Other & $0.093(0.061)$ & $0.163(0.067)$ & Child benefits & $0.063(0.021)$ & $0.081(0.026)$ \\
\hline Academic high school & $0.138(0.081)$ & $0.352(0.106)$ & Gross earnings & $0.130(0.020)$ & $0.085(0.021)$ \\
\hline $\begin{array}{l}\text { Fields within vocational high } \\
\text { school: }\end{array}$ & & & $\begin{array}{l}\text { Industry: } \\
\text { Mining and quarrying }\end{array}$ & $0.214(0.040)$ & $0.046(0.045)$ \\
\hline Natural sciences & $0.185(0.127)$ & $0.745(0.303)$ & Construction & $0.027(0.039)$ & $0.086(0.045)$ \\
\hline Manufacturing_machinery & $0.120(0.045)$ & $0.289(0.052)$ & Wholesale and retail trade & $-0.005(0.037)$ & $0.098(0.041)$ \\
\hline Electrical engineering & $0.120(0.052)$ & $0.361(0.058)$ & Finance, ins. and real & & \\
\hline Construction & $0.138(0.077)$ & $0.309(0.079)$ & estate & $0.167(0.132)$ & $-0.014(0.077)$ \\
\hline Other technical branches & $0.238(0.070)$ & $0.265(0.073)$ & Transport and & & \\
\hline Agriculture & $0.011(0.065)$ & $0.163(0.063)$ & Telecommunications & $0.019(0.037)$ & $0.097(0.042)$ \\
\hline Health & $-0.011(0.118)$ & $0.084(0.129)$ & Manufacturing-food, & & \\
\hline Business, trade, services & $0.099(0.068)$ & $0.280(0.069)$ & textile & $-0.021(0.029)$ & $0.046(0.034)$ \\
\hline Law & $0.539(0.348)$ & $0.617(0.119)$ & Manufacturing_-machinery & $-0.051(0.033)$ & $0.013(0.039)$ \\
\hline Teaching & $0.215(0.172)$ & $0.223(0.154)$ & Public admin., education & & \\
\hline Other social branches & $0.198(0.101)$ & $0.240(0.198)$ & and health & $-0.015(0.038)$ & $0.017(0.041)$ \\
\hline Other & $0.210(0.071)$ & $0.354(0.082)$ & Not known & $-0.089(0.082)$ & $0.135(0.112)$ \\
\hline Fields within university & & & Constant term & $7.877(0.046)$ & $8.431(0.060)$ \\
\hline education: & & & Adj. $R^{2}$ & 0.129 & 0.240 \\
\hline Natural sciences & $0.135(0.106)$ & $0.454(0.157)$ & No. of obs. & 1951 & 1627 \\
\hline Manufacturing-machinery & $0.274(0.074)$ & $0.571(0.082)$ & & & \\
\hline Electrical engineering & $0.300(0.069)$ & $0.746(0.130)$ & & & \\
\hline Construction & $0.275(0.076)$ & $0.569(0.104)$ & & & \\
\hline
\end{tabular}

Base $=$ junior high school graduates working outside Prague in agriculture, earnings net of tax and child benefits. Standard errors in parentheses. 
Table A6.-Earnings Regressions with Time-Varying Cofficients for Communism and Transition (Education in Years)

\begin{tabular}{|c|c|c|c|c|c|}
\hline & \multirow[b]{2}{*}{ Communism } & \multicolumn{4}{|c|}{ Transition } \\
\hline & & All & State & Privatized & DeNovo \\
\hline Education & $0.0166(0.0099)$ & $0.0219(0.0072)$ & $0.0276(0.0118)$ & $0.0273(0.0121)$ & $0.0308(0.0123)$ \\
\hline Education $\cdot t$ & $-0.0003(0.0007)$ & $0.0093(0.0020)$ & $0.0098(0.0050)$ & $0.0104(0.0039)$ & $0.0077(0.0030)$ \\
\hline Experience & $0.0236(0.0053)$ & $0.0285(0.0053)$ & $0.0349(0.0066)$ & $0.0256(0.0086)$ & $0.0283(0.0060)$ \\
\hline Experience $\cdot t$ & $0.0007(0.0005)$ & $0.0017(0.0014)$ & $0.0018(0.0030)$ & $0.0012(0.0026)$ & $0.0012(0.0018)$ \\
\hline Experience $^{2}$ & $-0.0005(0.0002)$ & $-0.0006(0.0001)$ & $0.0008(0.0001)$ & $0.0006(0.0002)$ & $0.0007(0.0001)$ \\
\hline Experience $^{2} \cdot t$ & $0.0000(0.0000)$ & $0.0000(0.0000)$ & $0.0000(0.0001)$ & $0.0000(0.0001)$ & $0.0000(0.0000)$ \\
\hline Prague & $-0.1257(0.0460)$ & $0.1506(0.0279)$ & $0.1911(0.0561)$ & $0.1111(0.0651)$ & $0.1856(0.0369)$ \\
\hline Child benefits included & $0.2282(0.0403)$ & $0.1194(0.0296)$ & $0.1817(0.0616)$ & $0.0512(0.0653)$ & $0.1136(0.0392)$ \\
\hline Gross earnings & $0.1328(0.0514)$ & $0.0420(0.0441)$ & $0.0863(0.0944)$ & $0.1133(0.0780)$ & $0.0360(0.0613)$ \\
\hline Gross earnings $\cdot t$ & $0.0899(0.1601)$ & $0.0176(0.0131)$ & $0.0628(0.0326)$ & $0.0302(0.0259)$ & $0.0216(0.0176)$ \\
\hline \multicolumn{6}{|l|}{ Industry: } \\
\hline Mining and quarrying & $0.2759(0.0553)$ & $0.0448(0.0548)$ & $0.1965(0.1287)$ & $0.0382(0.0792)$ & $0.2002(0.1094)$ \\
\hline Construction & $0.1337(0.0520)$ & $0.1287(0.0430)$ & $-0.0241(0.1255)$ & $0.1627(0.0707)$ & $0.0249(0.0578)$ \\
\hline Wholesale and retail trade & $-0.0540(0.0589)$ & $0.1186(0.0447)$ & - & $0.1844(0.0945)$ & $0.0110(0.0593)$ \\
\hline Public admin., education, and Health & $0.0937(0.0513)$ & $0.0650(0.0470)$ & $0.1244(0.1310)$ & - & - \\
\hline Finance, insurance, and real estate & $0.1161(0.2079)$ & $0.0047(0.0818)$ & $0.1294(0.1142)$ & $0.0406(0.1378)$ & $0.0489(0.0746)$ \\
\hline Transport \& telecommunications & $0.0963(0.0632)$ & $0.1010(0.0551)$ & $0.2232(0.1959)$ & $0.0060(0.1032)$ & $0.1819(0.1379)$ \\
\hline Manufacturing-food, textile & $-0.0021(0.0441)$ & $0.0253(0.0414)$ & $0.1072(0.1204)$ & $0.1721(0.1008)$ & $0.0753(0.0856)$ \\
\hline Manufacturing-machinery & $-0.0162(0.0494)$ & $0.0855(0.0482)$ & $0.0018(0.1171)$ & $0.0086(0.0634)$ & $0.0079(0.0569)$ \\
\hline Not known & $0.0639(0.1303)$ & $0.1963(0.1032)$ & $0.0351(0.1379)$ & $0.0778(0.1119)$ & $0.1842(0.1578)$ \\
\hline Constant & 7.9297 (0.1289) & $7.7520(0.0944)$ & 7.5578 (0.1799) & $7.6788(0.1553)$ & $7.8586(0.1707)$ \\
\hline $\operatorname{Adj} R^{2}$ & 0.172 & 0.285 & 0.384 & 0.269 & 0.356 \\
\hline No. of obs. & 1285 & 2107 & 483 & 1045 & 579 \\
\hline
\end{tabular}

Table A7.-EARnings Regressions with Time-VARying Cofficients for Communism and Transition (Education in Levels)

\begin{tabular}{|c|c|c|c|c|c|}
\hline & \multirow[b]{2}{*}{ Communism } & \multicolumn{4}{|c|}{ Transition } \\
\hline & & All & State & Privatized & DeNovo \\
\hline Apprentice (2 years) & $0.0566(0.1007)$ & $0.0783(0.1062)$ & $0.1532(0.1673)$ & $0.1542(0.1562)$ & $-0.0658(0.1635)$ \\
\hline Apprentice $(2$ years $) \cdot t$ & n.a. & n.a. & n.a. & n.a. & n.a. \\
\hline Apprentice (3 years) & $0.0690(0.0745)$ & $0.0489(0.0691)$ & $0.0950(0.1117)$ & $0.1185(0.1032)$ & $0.0865(0.0775)$ \\
\hline Apprentice $(3$ years $) \cdot t$ & $-0.0003(0.0051)$ & $0.0528(0.0206)$ & $0.0652(0.0217)$ & $0.0417(0.0216)$ & $0.0315(0.0150)$ \\
\hline Vocational HS & $0.056(0.082)$ & $0.051(0.074)$ & $0.0591(0.1243)$ & $0.2034(0.1169)$ & $0.1827(0.0911)$ \\
\hline Vocational HS $\cdot t$ & $-0.0014(0.0059)$ & $0.0768(0.022)$ & $0.1022(0.0323)$ & $0.0474(0.0217)$ & $0.0322(0.0191)$ \\
\hline Academic HS & $0.3378(0.1783)$ & $0.0896(0.1126)$ & $0.2993(0.1857)$ & $0.0585(0.2400)$ & $0.0133(0.1862)$ \\
\hline Academic $\mathrm{HS} \cdot t$ & $0.0104(0.0106)$ & $0.0335(0.0338)$ & $0.0367(0.0560)$ & $0.1037(0.0559)$ & $0.0315(0.0535)$ \\
\hline University & 0.1789 (0.0888) & $0.2675(0.0822)$ & $0.3302(0.1332)$ & $0.4048(0.1270)$ & $0.3160(0.1120)$ \\
\hline University $\cdot t$ & $-0.0047(0.0066)$ & $0.0996(0.0245)$ & $0.1168(0.0409)$ & $0.0762(0.0263)$ & $0.0987(0.0253)$ \\
\hline Experience & $0.0244(0.0054)$ & $0.0291(0.0053)$ & $0.0411(0.0063)$ & $0.0252(0.0077)$ & $0.0303(0.0057)$ \\
\hline Experience $\cdot t$ & $0.0009(0.00048)$ & $0.0002(0.0001)$ & $0.0026(0.0027)$ & $0.0033(0.0025)$ & $0.0016(0.0018)$ \\
\hline Experience $^{2}$ & $-0.0006(0.0002)$ & $-0.0006(0.0001)$ & $0.0009(0.0001)$ & $0.0006(0.0002)$ & $-0.0007(0.0001)$ \\
\hline Experience $^{2} \cdot t$ & $-0.00001(0.00002)$ & $-0.000004(0.000003)$ & $0.0001(0.0001)$ & $0.0001(0.0001)$ & $0.0000(0.0000)$ \\
\hline Prague & $-0.130(0.046)$ & $0.140(0.028)$ & $0.1629(0.0575)$ & $0.0794(0.0736)$ & $0.1667(0.0364)$ \\
\hline Child benefits included & $0.228(0.040)$ & $0.122(0.029)$ & $0.2099(0.0597)$ & $0.0493(0.0579)$ & $0.1126(0.0400)$ \\
\hline Gross earnings & $0.134(0.051)$ & $0.048(0.044)$ & $-0.0325(0.0904)$ & $0.0828(0.0779)$ & $0.0609(0.0631)$ \\
\hline Gross earnings $\cdot t$ & $0.004(0.004)$ & $0.002(0.001)$ & $0.0441(0.0305)$ & $0.0085(0.0264)$ & $0.0185(0.0180)$ \\
\hline \multicolumn{6}{|l|}{ Industry: } \\
\hline Mining and quarrying & $0.272(0.055)$ & $0.046(0.055)$ & $0.202(0.129)$ & $0.061(0.078)$ & $-0.206(0.111)$ \\
\hline Construction & $0.132(0.052)$ & $0.130(0.042)$ & $-0.0001(0.123)$ & $0.200(0.071)$ & $-0.001(0.059)$ \\
\hline Wholesale and retail trade & $-0.054(0.059)$ & $0.119(0.044)$ & - & $0.180(0.097)$ & $-0.014(0.061)$ \\
\hline Public admin., education, and health & $0.083(0.047)$ & $0.055(0.053)$ & $0.129(0.113)$ & - & - \\
\hline Finance, ins., and real estate & $0.083(0.053)$ & $0.095(0.055)$ & $0.188(0.167)$ & $0.103(0.095)$ & $-0.252(0.137)$ \\
\hline Transport \& telecommunications & $0.090(0.063)$ & $0.025(0.041)$ & $0.118(0.123)$ & $0.211(0.098)$ & $0.058(0.087)$ \\
\hline Manufacturing-Food, Textile & $-0.002(0.044)$ & $0.025(0.041)$ & $0.009(0.116)$ & $0.026(0.063)$ & $-0.037(0.059)$ \\
\hline Manufacturing-machinery & $-0.017(0.049)$ & $0.087(0.048)$ & $0.128(0.130)$ & $0.114(0.071)$ & $0.026(0.072)$ \\
\hline Not known & $0.068(0.131)$ & $0.182(0.099)$ & $0.030(0.148)$ & $0.091(0.130)$ & $0.136(0.149)$ \\
\hline Constant & $8.063(0.084)$ & $7.959(0.078)$ & $7.719(0.151)$ & $7.864(0.138)$ & $(8.148)(0.078)$ \\
\hline $\operatorname{Adj} R^{2}$ & 0.172 & 0.296 & 0.344 & 0.339 & 0.27 \\
\hline No. of obs. & 1285 & 2107 & 483 & 413 & 1045 \\
\hline
\end{tabular}

Base $=$ junior high school graduates working outside Prague in agriculture, earnings net of tax and child benefits. Standard errors in parentheses. 